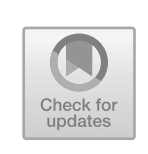

\title{
The Mandate of Heaven, the Rule of the Emperor: Self-Sufficiency of the Middle Kingdom
}

This chapter pays special attention to the analysis of the state administrative capacity of late Ming and Qing China by exploring the reforms introduced from the late sixteenth century up to 1796 regarding tax collection. Institutional constraints will be further explored through the rooted mandarinate system and despotic rule of the emperor and officials who fostered the multiplication of institutions, mainly during the expansion to western provinces throughout the Qing dynasty. A highly bureaucratized system thwarted stable economic growth in the Middle Kingdom which reached its peak in the Song dynasty. The self-sufficiency of China showed by Qing (foreign) non-Han despotic rulers under the undisputable power and mandate of the emperor set Qing China onto a divided path. One direction would either modernize the country through acquisition of new technologies and economic reforms via economic and cultural transfers with the West; the other would close the borders and keep tight control of the newly incorporated western territories. This was a "supremacy dilemma" and a "power paradox" model that can be applied to the Middle Kingdom, and by extension to highly interventionist polities and countries. The firm exercise of power and control of society, the coercive forces implemented to keep such dominion, and the creation of a complex bureaucracy with incompetent institutions all prevented sustainable economic growth and state capacity within Qing China. A deep

M. Perez-Garcia, Global History with Chinese Characteristics, Palgrave Studies in Comparative Global History, https://doi.org/10.1007/978-981-15-7865-6_3 
analysis of the Local Gazetteers of China [zhōngguó difāng zhi 中国地 方志] serves as an indicator to test the low state capacity to regulate Qing China.

\subsection{Post-Needham Practices: Uniqueness of Chinese Civilization AND Economy?}

The vast geography of China, alongside the variety of economic resources and rich land, provided the Middle Kingdom with advantageous conditions to reach higher levels of economic development than its European counterparts. Scholarly research on China's economic history acknowledges that the Song Dynasty (960-1279) (Deng 2000) was the most prosperous period, surpassing that of medieval Europe. The use of Gross Domestic Product (GDP) as a modern economic indicator, and its backwards projections to year $\mathrm{l} \mathrm{AD}$, seems invalid when analysing early modern economies and polities of Eurasia, mainly China (O'Brien and Deng 2017). Dwight H. Perkins (1969) and Albert Feuerwerker (1976) acknowledge a dramatic growth in China's marketed agricultural output, circa $20-40 \%$, from the Ming dynasty to the late Qing dynasty. In less advanced areas of northern China, from George William Skinner's analysis, we might deduce some symptoms of proto industrialization (Chao 1986; Wong 1997), earlier than in eighteenth-century western European regions, as farmers increased their incomes from market and artisan activities creating a dynamic trade network connecting rural and urban areas (Skinner 1964, 1971).

In the Song dynasty the large circulation of minted-iron coins, and ingots, dynamized regional markets fostering an economy based on monetary metal for individual transactions, but without a standardized system. The annual iron output during this period reached circa 150,000 tons (Harrison 1972; Hartwell 1963). In addition, during the seventeenth and eighteenth centuries the exports of porcelains, silks, and teas (Perez-Garcia 2013) grew rapidly to satisfy the European craze for Chinese exotic goods. The Middle Kingdom since the Song dynasty had advantageous conditions to reach high levels of prosperity and modernization, much earlier than the western European experience of the eighteenth century, but the Middle Kingdom lacked a sustainable model to keep its economic growth in the long run. I put forward the thesis that institutional constraints and the creation of a complex and inefficient bureaucratic system created in the Qing dynasty, a dynasty based on the 
military force to control the newly conquered territories, was one of the main causes that made China's economy stagnant.

The so-called Sinological trend in Chinese economic history research, which was mentioned in Kent Deng's work (Deng 2000), has some special characteristics, perhaps in line with the "Chinese characteristics" mentioned in the previous chapter, beyond the overwhelming praise about the Middle Kingdom's unique conditions of economic development in premodern times at the dawn of the European Renaissance (Mokyr 1990). This scholarly view has more significance following current PRC studies that develop national narratives inherent to Sinocentric views positioning the Middle Kingdom, or China (as modern term), in the centre of the world. This assessment has prevailed from imperial times until today serving in PRC scholarship as a patriotic flag to present the uniqueness of China's history and civilization.

This perspective, but with different connotations, was rooted in the Song dynasty wherein Sinocentrism and neo-Confucianism was established by converging Taoism, Buddhism, and Confucianism. This explicitly set, for the first time in the Middle Kingdom, the concept of supremacy and self-sufficiency by the emperor and his ministers. The improvements during the Song dynasty in agriculture (land use and irrigation systems, efficient labour force, output distribution) (Deng 1993; Ho 1959; Rawski 1972; Perkins 1969; Elvin 1973; Needham and Bray 1984; Huang 1985; Smith 1988), technological discoveries, in which some of these innovations were made in the Tang dynasty, such as metallurgy, gunpowder, the compass, nautical devices, paper making and currency, manufacture of silk, tea, and porcelain, as well as credit institutions and dynamic networks of commerce and transportation, all created the preconditions in a special environment for the possible rise of capitalism and modern science.

But why did the industrial revolution and modern science not occur during the Song dynasty, and why did it take place much later in eighteenth-century western Europe, mainly in Great Britain and the Low Countries? This is the well-known Needham's puzzle that seeks answers about why modernization and economic development did not take place in Song China when it had all the preconditions for a socio-economic and cultural transformation of the country (Needham and Wang 1954). Self-sufficiency and supremacy, however, were embedded within China's institutions (Ma 2012), rulers, and the Mandate of Heaven [tiānming 天命], symbolized in the emperor as the superior being governing his 
subjects and life of the kingdom. This cultural mindset set from the Song dynasty to the deeply rooted alien (non-Han) Qing emperors, to modern China with the Republic and then the founding of the PRC, resulted in the economic and social life of the country being straightjacketed into the conditions of an interventionist and mercantilist system (de Bary 1993). This motive is rooted in the cultural beliefs and the rigid hierarchized society (Kishimoto 2011). Supremacy of the state limited the social dynamism and economic growth of China from imperial times until today.

Technological and economic breakthroughs have occurred in any historical period across time and space. The key factor in maintaining and stabilizing regional economies, dynamizing markets, and fostering local demand is to implement efficient policies that reduce bureaucracy, the appointment of officials, and any unnecessary institutions. A rise in investments for innovation based on the individual action of the market agents is a crucial element for the sustainability of the economy.

However, the European (mainly in southern European countries, i.e. Spain, Portugal, France, Italy, and also Northern Europe) (de Vries and Van der Woude 1997) and the Asian (Chinese) experience of the early modern period to break free from institutional constraints was doomed to fail (Ogilvie 2011). A clear example is the artisan and merchant guilds of Spain (Pike 1966; Iradiel 1974; Casado 2004; Yun-Casalilla 2019) and Qing China [buiguán 会馆] (Quan 1993), which aimed to regulate quotas of production, exports, imports, prices, and output distribution thus limiting the action of the market and economic agents (Shiu and Keller 2007). In many cases these institutions acted as self-governing organizations (Chen 2001) controlled by local elites and the gentry creating therefore a parallel institutional system.

The transition from feudal systems to capitalism and a market-driven economy is based primarily in the reconversion of primary sectors of production (agriculture and the traditional workshop system) into the factory organizational system. This transformation of the economy, from medieval and premodern forms of production based on the control and restriction of the forces of production and limiting entrepreneurship, innovation, and specialization of the labour force to foster an efficient economy according to the environment or milieu, might be applicable in the long run to better grasp the constraints encountered by socioeconomic agents. Institutional constraints derived from a highly bureaucratic system posed limitations to matching the gap on economic growth 
Table 3.1 Matching the gap on economic growth: from institutional constraints to free market economy

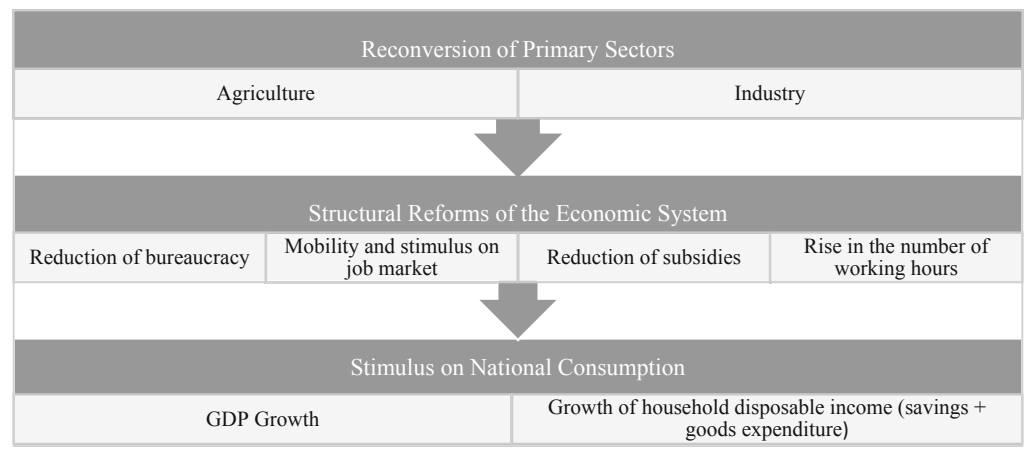

Source: Author's own elaboration

between East Asian regions and advanced areas of Western economies (see Table 3.1).

As with agrarian-based economies which are orientated around primitive forms of production with feudal features such as latifundia in Latin America (Frank 1969), or even in some regions of Mediterranean Europe during the twentieth century where land management by elites constituted the main source of political power, the transition to a free market system (see Table 3.1) has not taken place equally in East Asian regions. The lack of structural reforms in East Asian regions such as China in which the reduction of bureaucracy and fostering at the same time a stimulus job market based on mobility and incentives (social promotion and meritocracy) might be pinpointed as one of the main reasons for the gap, not only between China and western European economies, but also among socio-professional groups within China's provinces.

Reducing the number of inefficient and unnecessary officials, as well as the elimination of subsidies (see Table 3.1) seems a difficult task in interventionist, self-sufficient, and mercantilist economies. Within such traditional and power-driven societies, the prevalent feature of favour exchanges, deeply rooted in primitive societies in which the "gifts"/“donations" (Mauss 2006; Racine 1979; Caillé 1991) constituted the invisible force for the perpetuation of power of the ruling elites (from feudal lords to landlords and government ministers and officials), limited the possibilities of creating "open societies" and thus widened 
the economic gap among social classes, income inequality, and wealth distribution in regions and provinces.

Certainly in different periods of China's economic history from the Song to the Qing dynasty, and also during the twentieth century, the rise in the number of working hours per household allowed for an increase in the level of income due to family members holding several jobs as market producers, and also their participation in local exchanges as market consumers. This has allowed economic historians to detect symptoms of the "industrious revolution" as a previous stage of the consumer revolution and, therefore, economic modernization of the country (Hayami 1976, 2015; de Vries 2008; Perez-Garcia 2013). Features for an "industrious revolution," "hardworking creates earlier spring" [rén qín chūn lái záo 人勤春来早] in China might be detected in eastern regions ( $\mathrm{Li}$ 1996, 1998). However, no economic or technological breakthroughs occurred due to the institutional constraints mentioned above, which only prompted symptoms or "sprouts of capitalism" in coastal areas of China, i.e. Jiangsu, lower Yangtze delta, and Jiangnan (Fig. 3.1).

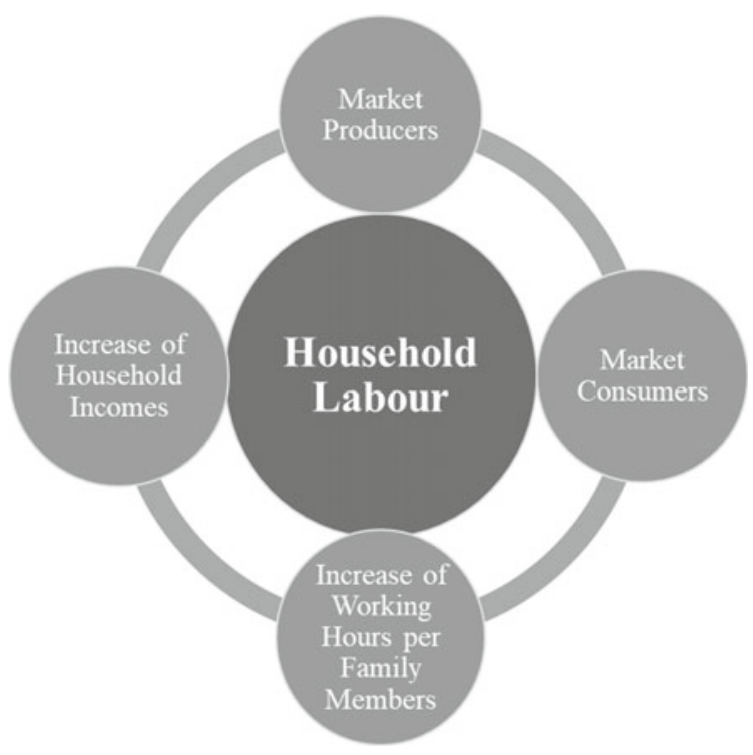

Fig. 3.1 The "industrious revolution" model

Source: Author's own elaboration 
GDP is an invalid economic indicator to measure economic growth. The stimulus on consumption constitutes the main artery of a dynamic economy as capital circulates smoothly among the economic agents who are less dependent on credit and subsidies and, thus, the direct intervention and regulation of the state. However, GDP in modern times champions as an economic measure to weigh world economies serving, therefore, as an instrument embedded with nation-states' supremacy and hegemonic power. ${ }^{l}$ For the case of China there is no doubt that GDP might be metaphorically related to collective forces of production led by the state, the communal spirit of the nation, against the individualism or sole action of market agents on freely choosing consumer goods. In addition, carrying out entrepreneurship, marginal savings, and health security are features that consequently lead to the modern welfare state and development of the middle class as a cornerstone of developed regions based on a sustainable economic growth model.

China's current economic rise has reinforced the country's hegemonic role through GDP. However, this economic measure is based on production forces of the economy (nation), but not to the wealth and income distribution as major drivers of the demand side which is where the prosperity of any economy and the middle classes lies upon. Thus, GDP somehow has contributed to perpetuate the bipolar economic world (core-peripheries) (Wallerstein 1980) inherited after WWII, in the Cold War period, and between Western and Eastern economies locating one sole economic centre or hegemonic power in either region. This has exacerbated national exceptionalism and the spread of patriotic ideas which today are very much present in China.

During the early 1990s, in the dawn of globalization and after the collapse of the Soviet Union, a time of world economy reorganization within socio-economic and political reforms, Andre Gunder Frank attempted to correct such misleading arguments on economic history analysis by introducing the concept of polycentrism (Frank 1998). This proposes that there is no one dominant economic centre, but rather that

${ }^{1}$ GDP served to boost western (Eurocentric) exceptionalism as an economic national measure formulated by Simon Kuznets in 1937 during the time of the Great Depression (Eichengreen 2015), and later adopted at the Bretton Woods conference of 1944 (Eichengreen 2006). As it is a measure created in times of autarky aiming to reach equilibrium of the balance of payments, it has national and neo-mercantilist implications to boost national production and reduce imports (Kuznets 1967). As an economic measure, GDP has contributed to a sort of national exceptionalism in world economies. 
a holistic view is essential in which all world regions have a crucial role being interconnected with each other.

Frank shifted the focus of world economies to Asian regions challenging, thus, the prevalent Eurocentric perspectives on global (economic) history analysis (Landes 1998). The challenge to the Eurocentric approaches (Duchesne 2001) was based on the following arguments: (1) living standards of Chinese households were equal to or higher than European regions before $1800 ;(2)$ local markets in eastern regions of China (Yangtze delta, Jiangsu province) had an efficient system that could match its European counterpart regions; (3) improved agricultural techniques and irrigation systems were in place; and (4) both Chinese and European regions had to cope with Malthusian pressures.

These four findings established that East Asian regions were the main developers of a world market economy setting the Middle Kingdom in current scholarship as the main economic centre (Perez-Garcia 2014). However, this flourishing economic period ended circa 1796, mainly in China during the so-called "High Qing” period [shèng qing 盛清], and consequently northwestern European regions (Great Britain and Netherlands) took off and China stood behind. This decline, according to the scholarship, was due to the outbreak of the White Lotus Rebellion and the subsequent economic depression during the reign of the Daoguan emperor (1820-1850) (Von Glahn 2018). The Middle Kingdom's dominion, which was the main territory fostering this global market economy, had ended by the end of the eighteenth century. As I will show in the following sections, the benign view that some scholarship has given to China's economy of the eighteenth century for the "High Qing” period [shèng qing 盛清] (Wong 1997; Li 1998; Von Glahn 2016) dismisses the fact that the stiff control of trade, mainly during the period of the Yongzheng emperor and the Qianglong emperor and his establishment of the Canton system, created in the long run a negative effect on the economy and society.

In economic terms, the bureaucracy and inefficient administrative system of the Qing emperors showed their inability to manage trade, especially with the constant influx of American silver to private elites that did not revert back into the state coffers. And also, the handicapped economic administration of the alien (Manchu, non-Han) emperors and their dominance of both maritime and inland trade routes aimed to control the Han population to avoid uprisings and internal rebellions. Both rigid mercantilist decrees and control of the Han population deserve to be further 
examined as relevant factors which in the long run pushed back China's economy.

Quantitative analyses of China's economic development, mainly those following Maddison's estimates (Maddison 2001, 2007) and research line (Broadberry et al. 2017; Li and van Zanden 2012), dismiss these qualitative dimensions of the Qing economy in the eighteenth century. In addition, the use of macro-aggregates economic indicators such as GDP does not fit well for early modern economies (see Fig. 3.2) (Allen et al. 2005; Broadberry and Gupta 2006; Allen 2009; Broadberry and Hindle 2011; O'Brien and Deng 2017) and has led to conclusions about how the great divergence took place in the late eighteenth century when Great Britain took off during the first Industrial Revolution, and China, therefore, stood behind. According to this interpretation, before the year 1500, Europe had minimal influence in the world economy, but when the Americas became the main supplier of economic resources (Pomeranz 2000 ) the so-called "European miracle" of industrialization (Sugihara 1996; Pomeranz 2000) came to fruition. This conclusion is blurred by a Eurocentric perspective which puts the accent on the British exceptional momentum of the eighteenth century. Locating dominant centres

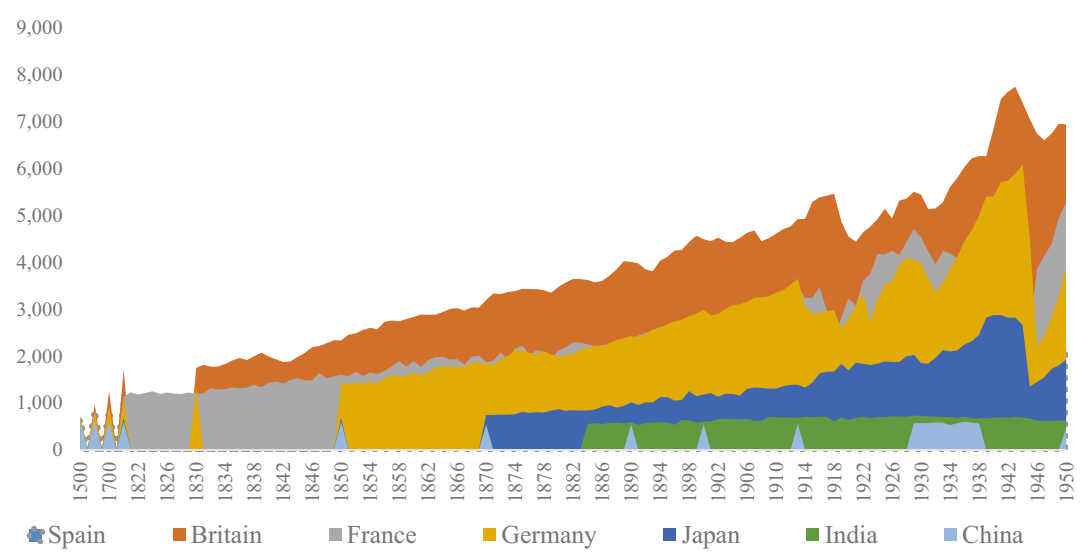

Fig. 3.2 Per capita GDP (1990 international Geary-Khamis dollars)

Source: Maddison, A., Monitoring the World Economy 1820-1992, Paris: OECD Development Centre, 1995. Maddison, A., The World Economy: A Millennial Perspective, Paris: OECD Development Centre, 2001. Maddison, A., The World Economy: Historical Statistics, Paris: OECD Development Centre, 2003 
following Wallerstein's analysis of core-periphery dismisses the role of other world regions and connectivities. A more holistic view of such processes of cultural and scientific achievements in which institutional and religious constraints were the main obstacle for economic development is necessary when comparing East Asia (China) and its European counterparts. The role of institutions and elites is crucial in a transition to a scientific revolution, which reduces the intervention of the state, freeing the market, and therefore giving more space to individualism in which scientific and technological innovation is rooted.

To achieve technological innovations and set the path towards modernization, the Scientific Revolution and modern science in Europe emerged from the tensions between Christian theology and natural philosophy during the Renaissance having as a result the displacement of the Aristotelian understanding of the natural world (O'Brien 2013). Religious and political tensions that crystalized in a dense network of institutions, inherited from medieval feudal systems and adapted to European regimes of the early modern period, served as the main obstacle for scientific breakthroughs. It might be inferred, thus, that the Scientific Revolution that took place in some European regimes by the late seventeenth and early eighteenth century following the Galilean and Newtonian methods, also followed as well the Aristotelian tradition of world order and scientific knowledge.

It has been argued, therefore, that this process of acculturation and scientific discoveries turned into a process of global conjunctures in which in some European polities, mainly northwestern Europe (Great Britain and the Netherlands), modern science was reordered into a new cosmographical belief system (Weber 1950, 1951, 1958; Needham 1969). Within this system new institutions were organized into a more productive way so that the forms of production, knowledge, and technologies could serve the formation of modern nation-states and the consolidation of emerging empires. Such an explanation is rooted into the Eurocentric tradition of global economic history by which the British empire and its colonies are located as the hegemonic power during the late seventeenth and eighteenth century.

Thus, the European Scientific Revolution (Gillespie 2008; Huff 1993; Lindberg 2007; Levine 2001), which matured in the first Industrial Revolution at the end of the eighteenth century, has been analysed more as a world economic process than a cultural process that succeeded in specific regions in which individualism was gaining more terrain to the detriment 
of semi-feudal ruling elites and institutions that limited innovation and knowledge (Clagett 1959; Epstein and Prak 2008; Hall and West 1976; Gies and Gies 1994; Gimpel 1977). Following such a linear process that assumes the dominant position of northwestern European regions in the world economy after 1750, the analysis and the question of why such European regions took off and China stood behind, or why modern science and capitalism emerged in Europe and not in China, is biased from the beginning through the Eurocentric perspective.

The reason for such bias is that economic analysis and interpretations should consider the cultural aspects and dramatically hierarchized East Asian (Chinese) society which did not undertake the transition to individualism, and/or substitution of semi-feudal institutions and ruling elites that were very powerful in south China provinces where the capital (American) silver accumulation did not revert into technological or scientific investments. This self-sufficient and hegemonic exceptionalism of China was rooted since the Song dynasty in neo-Confucian policies and Sinocentrism where a rigid social hierarchy limited individualism, technological breakthroughs, and, therefore, a scientific revolution that might have consolidated, in the long run, economic growth and development in the Qing dynasty.

\subsection{Institutional Constraints: Feudalism, "Nosphimeric Bureaucratism," AND Mandarinate}

According to the interpretations of the California School (Von Glahn 1996; Flynn and Giraldez 2010; Li 1998), and mainly Pomeranz's work (2000), European regions were progressively surpassing their Asian counterparts through the exploitation of American resources and the implementation of European institutions in the New World. In addition, Europeans were gaining terrain in Asian markets and the Pacific region. American silver and the natural resources of the Americas allowed European regions, mainly northwestern Europe, to develop faster. However, according to the economic resources available in the vast geography of the Middle Kingdom and the growing accumulation of American silver since the Ming dynasty which might have offered both China and northwestern Europe the same conditions for economic growth, then we should ask: why didn't China achieve a sustainable economic growth when it had both the natural resources and a great accumulation of American silver as main world currency? 
I believe the answer lies with a number of factors: the institutions, the inefficient bureaucracy that proved to be handicapped when coping with population growth and tax reforms, as well as the corruption of the gentry and local elites (Chang 1962) who had accumulated American silver through smuggling activities. In addition, the extremely hierarchized society based on neo-Confucian values and self-sufficiency of the state and the mandarinate also prevented China from achieving higher levels of economic growth. In the next chapter, I will develop this argument by cross-referencing historical sources that prove the failure of institutions and state capacity.

The key aspect is to observe whether individualism penetrated into Ming and Qing China to the detriment of the stiff interventionism of the state through feudal institutions, lords, and supervision of government officials. We know that this transition did not take place in China during the imperial period. The Middle Kingdom was from its early days looking inwards as the expansion of its borders was mainly westwards, whereas the expansion of European empires was orientated overseas. According to Euro-centred scholarship, mainly Ricardo Duchesne's work (2001), Europeans were no more rational than Asians as they based the expansion of their territories and extraction of economic resources on military force and implementation of coercive institutions based on slave and colonial trade. This was accompanied by a marginal increase in European wages, as well as costs of production derived from investments in new techniques and technological innovations.

Frank's affirmation that from 1400 until 1800 the hegemon of the world economy was Asia (Frank 1998), and therefore, China was the end-market of silver and gold flows, whereas other interpretations suggest that European powers exerted the monopoly since the sixteenth century (Landes 1998; Vries 2003), should be re-evaluated considering why such silver flows in China did not revert into technological innovations and economic growth.

European feudalism and social groups were based on a rigid social division and separation in estates or castes, i.e. clergy, nobility, businessmen, court and administrative officials, master artisans, artisans, peasants, yeomen, etc. This system was basically dominated by the ruling elites such as military aristocracy and landowners where inheritance and succession were based on primogeniture, where the firstborn son gained all rights. 
Chinese feudalism, on the other hand, was based on imperial examinations to select the most talented candidates for the state bureaucracy. The civil service examination system [kejjuzhi 科舉制] (Man-Cheong 2004; Miyazaki 1981; Ch'ü 1957) was implemented during the midTang dynasty and reached its apogee in the Song dynasty to ensure that state bureaucrats and officials were the most talented ones. This system of carrière ouverte aux talents [open career to talents] had no precedent in European Medieval kingdoms, and its early implementation in China could have potentially created an environment conducive for technological breakthroughs, diffusion of knowledge and innovation, and ultimately economic growth and modernization.

The European Renaissance was based on testing mathematized hypothesis about nature separating scientific and religious laws. This set the grounds for the European transition to capitalism during the sixteenth century in which the main features were discoveries by Galileo, Torricelli, the rise of the bourgeoisie, the emerging city-states, and the Protestant Reformation with its emphasis on individualism, entrepreneurship, and innovation. The role of cities or towns and the exercise of power and intervention of state institutions in Chinese and European regions are relevant when observing the transition from a feudal to modern system.

The management and power executed by individuals in state institutions is essential for an efficient functioning of the administration and ultimately for successful development of the state capacity. Joseph Needham coined the concept "nosphimeric bureaucratism" (Needham 2004) by which we might test the effectiveness of state capacity in social, economic, and political terms in delivering a well-governed society. "Nosphimeric" derives from the sphere of human thought and how the individual's behaviour is driven for an efficient performance of his tasks based on a set of rules, ethics, and morals. The word derives from the Greek voũs [nous "mind"] and $\sigma \varphi \alpha \tilde{i} \rho \alpha$ [sphaira "sphere"]. The use of this word might have a "non-pejorative" connotation for the word "corruption" as a characteristic of the bureaucracy in China, which was growing during the Ming and Qing dynasties because of the continuous flows of American silver accumulated by the local elites and gentry of the southern provinces. Therefore, civil service, complex bureaucracy, and the mandarinate as executive power were intertwined factors that shaped a complex and arcane administration in China based on the hierarchy and mandate of the superior social rank, ultimately limiting social mobility. 
These three interconnected factors, plus the self-sufficiency of the Middle Kingdom which reached its peak in the Song dynasty, were in the long run responsible for the stagnation and limited modernization of China. Benign views of China's economic development from the fourteenth century onwards put the accent on Needham's puzzle by dismissing these three factors (civil service, complex bureaucracy, and the mandarinate) plus the self-sufficiency that characterized hegemonic powers, and therefore such scholarship has only limited the analysis to the failure of supply and demand technologies (Lin 1995).

Justin Yifu Lin's re-evaluation of Mark Elvin's high-level equilibrium trap thesis based on the rapid population growth of China as the main factor for the stagnation of China's economy and incentives for technological innovation asserting that "Chinese family's obsession with male heirs to extend the family lineage encouraged early marriage and high fertility" (Lin 1995: 271) is not accurate. The very same problem was encountered by western Mediterranean kingdoms at the end of the fifteenth century (if not earlier) when the Spanish Catholic monarchs repelled the Muslims from the Iberian Peninsula.

Extended lineage based on male primogeniture with the heir to accumulate and expand the wealth of the family by establishing coalitions and arranging marriages with families of similar or higher status was a common feature in Mediterranean Europe, and also in northwestern Europe (Casey 1989, 2007). The entailed state [mayorazgo] in the Iberian Kingdoms and the morgadio in Portugal (Yun-Casalilla 2019), aimed to keep the lands and assets of the family in the hands of the eldest son, resulting in early marriages and high levels of fertility to find heirs and, therefore, preserving the lineage's wealth. The family size was between two and four members per household (see Figs. 3.3 and 3.4) in which there was a mixture between nuclear and extended family.

Thus, the similarities in extended family lineage systems in both European and Chinese regions could also prove an obstacle for economic development and incentives to invest in new technologies in both regions (Goody 1983). But here we should distinguish between Mediterranean (Catholic) and northwestern (Protestant) Europe (Delille 2003; Stone 1979; Owens 2005). In the Catholic states, kingdoms, landlords, and institutions were a detrimental factor against technological investment as institutions such as the aforementioned entailed state, as well as craft and merchant guilds (Ogilvie 2011), prevented any technological innovation in order to keep a monopoly on the exploitation of the economic 
3 THE MANDATE OF HEAVEN, THE RULE OF THE EMPEROR ...

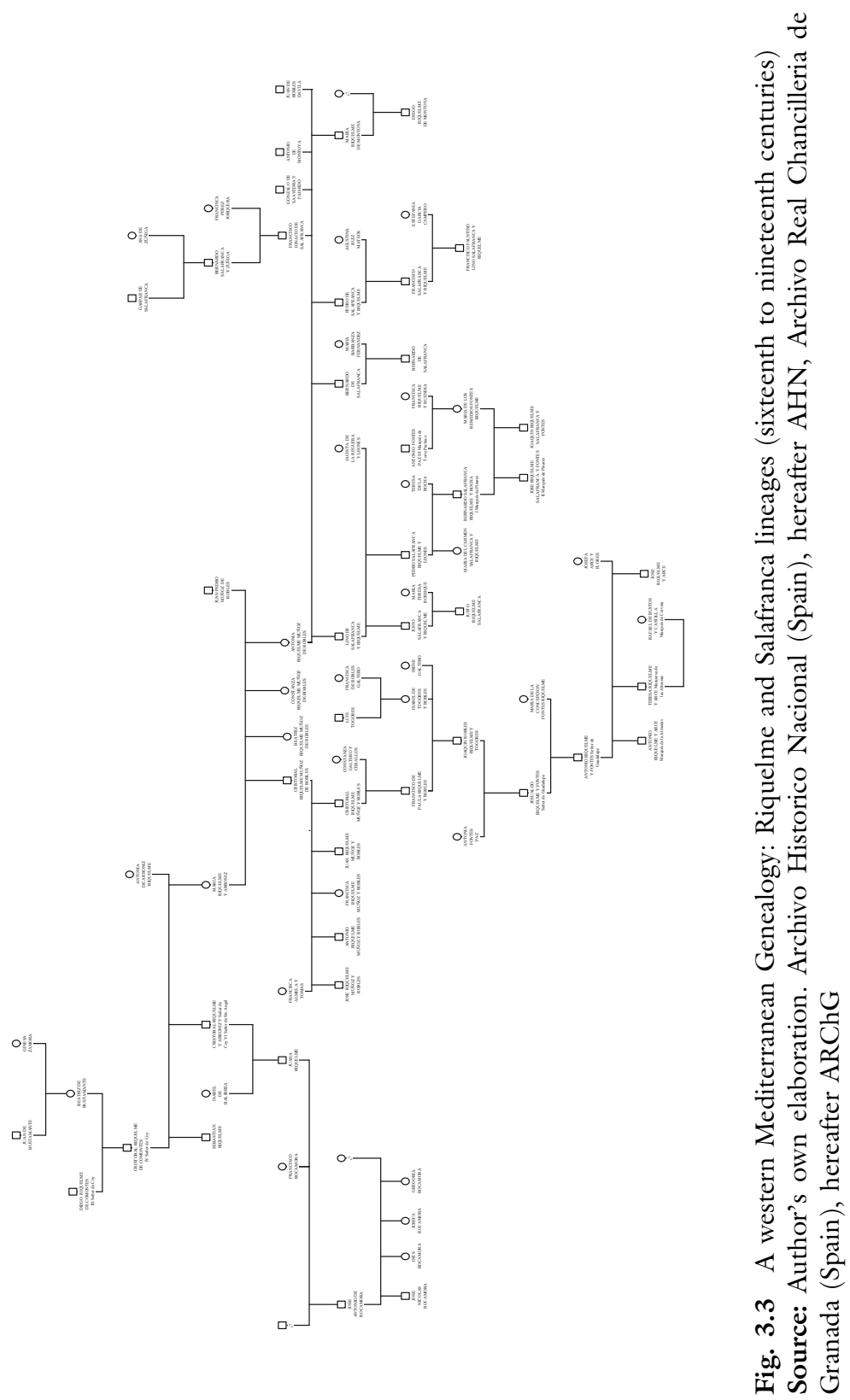


84 M. PEREZ-GARCIA

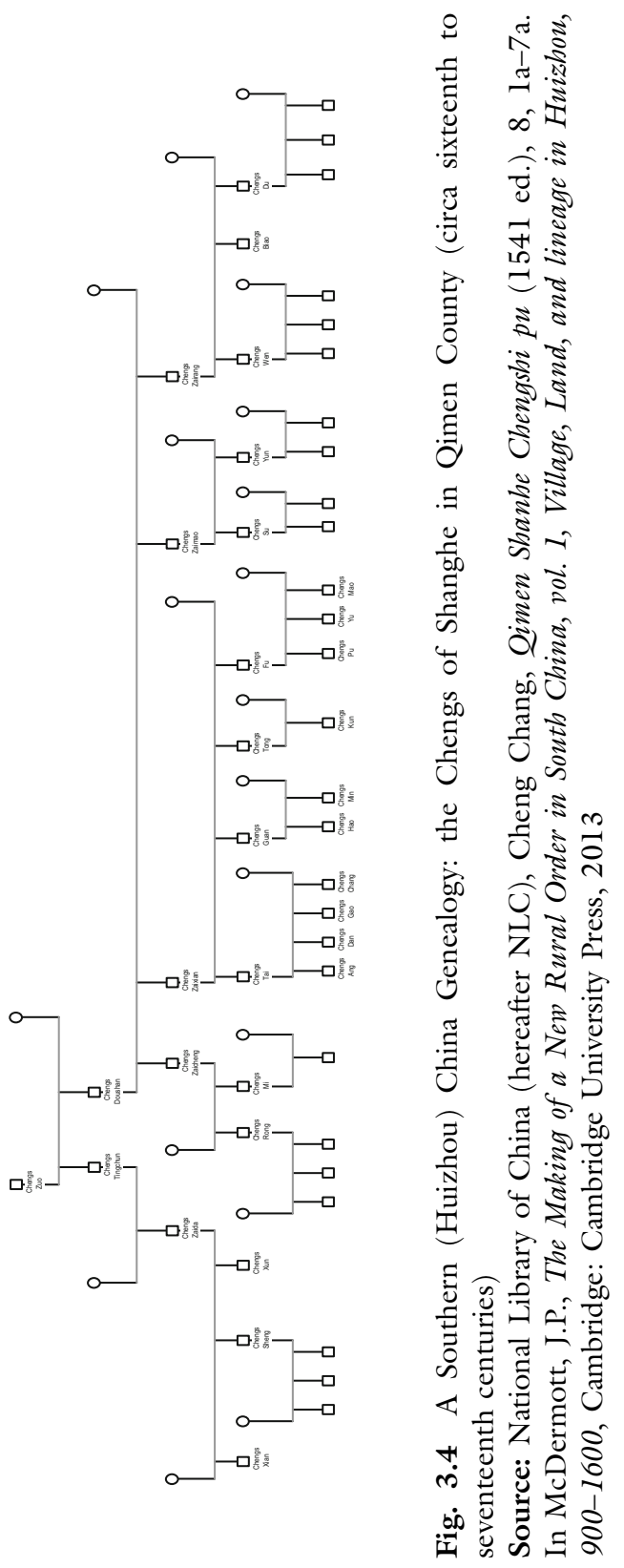


resources (land, labour, capital, raw materials, technologies). Whereas in Protestant Europe, entrepreneurship and implementation of new technologies had less constraints due to the cultural implications of the Protestant ethic, less intervention of the state, and the development of individualism.

This goes in line with Max Weber's theory on the Protestant ethic as main driver for the development of modern capitalism (Landes 1998). Its absence in the institutions of Catholic Europe and Qing China was the major constraint that hindered incentives for entrepreneurship, incentive for innovation, and sustainable economic growth (North 1991). Absolute states and multiplication of institutions (Acemoglu et al. 2005) whose main goal was to perpetuate local elites in power, either by the Mandate of Heaven in imperial China (Chao 1986; Elvin 1973; Tang 2006), or the divine monarchies of western Mediterranean Europe (Vilar 1974; Braudel 1949, 1996; Anes 1994), contributed to economic stagnation and lack of modernization. The rationale and despotism of Chinese and European elites could be similar in the use of labour, institutions, and economic resources (Anderson 1987).

As noted earlier, in European regions the power structures and society were divided into ranks based on military-aristocratic feudalism, whereas in China the socio-economic and political structures rested upon bureaucratic feudalism and the civil service examination system established in the mid-Tang dynasty and consolidated in the Song dynasty. In the paradigm of the former type of feudalism, power was managed by medieval knights who conquered new land and conveyed it to next generations in which lineage and family was the main institution to safeguard the wealth of the elites. This system granted relatively small power to the emerging group of merchants in the cities who, in the transition from the medieval to early modern period, assimilated with the old nobility and knights who conquered new lands and managed the economic resources of feudal estates (Perez-Garcia 2020). This transition and the collapse of the medieval feudal system at the dawn of the sixteenth century within the expansion of European powers to the New World prompted the rise of bourgeoisies triggering, in the long run, the road to the Industrial Revolution and incentives to seek technological breakthroughs in some urban areas of northwestern Europe.

In contrast, the hierarchical social structures in Ming and Qing China in which merchant groups were at the bottom of society made social assimilation and promotion much more difficult (rich merchants through 
their fortunes could also buy official titles). Ultimately such rigid social structures thwarted a smooth transition from feudal structures to a bourgeoisie-based institutional system as a prelude to forming an open society in which the circulation of people, capital, technology, and goods could open the path to economic growth.

China's bureaucratic feudalism acknowledged the emperor as the sole authority of the territory under which there was a highly powerful and centralized government (Adshead 2004) where the territories were unified around the Middle Kingdom in the Qing dynasty under the scope of the "great unification" ( $\mathrm{Li} 2012,2014)$. The absolute power handled by the emperor, officials, and governors prevented merchant groups and business families from achieving social promotion and assimilating with families of higher status who had an official title. The bureaucratic feudalism based on official titles and political status around imperial Court and government institutions was orientated towards consolidating and unifying state power through the recruitment of skilled leadership. So in contrast to European regions where the male heir was the only legitimate successor of land and family assets, China's socio-political power since the Song dynasty was based on recruiting individuals as officials based on talent after passing the official examination system.

As a result, the central government was full of talent. This might provide some clues as to why China's government was more advanced than its European counterparts during medieval times, but this also set China onto a system in which power was highly concentrated into the hands of small elite groups preventing the rest of society's lowermiddle classes to achieve social mobility. The high concentration of power held by elites around the Court and government institutions thwarted the unification of the Middle Kingdom when its lands were expanding westwards after the Qing (Manchu alien emperors) arrived in the midseventeenth century. Such concentration of power created tensions in the long term between established political elites, "small family dynasties" that passed the examination systems and consolidated their political status around the Court and local institutions in villages and small cities, and the rising new rich families that were making their fortune in trade by accumulating capital (American silver).

Consequently, it seems quite relevant to observe the structure of the formation of bourgeois city-states of western European regions in contrast with the concept of "citizenship" (if we might apply this concept) or urban identity in China. In Ming and Qing cities or urban areas, nodes of 
administrative political networks of the central government can be identified. The crucial question is how the state was able to efficiently manage such a complex administration especially in the Qing period when land accumulation and population growth were both rapidly increasing. In the case of some European regions, small city-states were ruled by the lords who granted powers to rich business elites, and these groups in return recognized the power of their lord invested through divine powers.

The city was regarded as land property of the lord, the feudal patron, who protected and defended it (de Vries 1984). This structure of power acknowledged the leadership of the lord and patron, but also granted at the same time some agency to the emerging rich and bourgeois groups participating in local institutions and taking part in the political decisions of the city-state (i.e. Amsterdam, Lyon, Turin, Venice, London, Stockholm, Marseille, Cadiz, are outstanding examples). This allowed for a certain amount of cohesion and a balance of power that generated a unified stance to consolidate the domestic structures of the city and efficiently secure and defend it from potential attacks of other cities or kingdoms. The consequence of the distribution and consolidation of power in the socio-political structures of the city fostered flourishing market-orientated family groups emerging in urban areas where merchants invested profits and institutions and power into the hands of these trade elites.

However, for the case of China, especially during and after the Song dynasty through the implementation of Sinocentrism and neo-Confucian policies, self-sufficiency characterized people's daily lives. This occurred even in periods of scarcity and lack of supplies, as it was the central government who coordinated and administrated rural areas and cities around provinces, prefectures, and counties to assist and aid the cities that were in need. In return, the government levied taxes on local communities and families [ding 丁] (Huang 1974; Ho 1959; Cao 2001; Elvin 1973). In this way, the socio-economic and political structures of ancient central government of China functioned as a trade/business entity among cities and villages ( $\mathrm{Li}$ 1981). The state created parallel state structures with a clear trade orientation, and in many cases diverted revenues to private pockets.

Therefore, the growing merchant communities of the Ming and Qing dynasties, mainly in the southern provinces, found that there were no proper political structures and ecosystems to institutionalize their activities. They were not operating under the protection of the government, 
and consequently they were forced to act outside the officialdom. This unbalanced economic system and unequal distribution of power, in contrast with the emerging city-states and burgs of early modern European regions, doomed imperial China to collapse when domestic tensions emerged in mid-Qing China due to the high accumulation of American silver in new rich communities that had made their fortune through overseas trade.

Questioning the state capacity of Qing China could be linked with Karl Wittfogel's classic thesis on the "Asiatic Mode of Production" (Wittfogel 1931), in which the bureaucratic structures created by the state aimed to control society through despotic and self-sufficient rule. The coined term "Oriental despotism" (Wittfogel 1957) emphasizes this idea of the sole and unquestionable mandate of the emperor (and mandarinate system) centralizing power with the goal of keeping the kingdom unified. This ultimately prevented the economy from moving onto the later phases of economic development when China had the preconditions to develop as modern an economy as Great Britain or the Netherlands in the eighteenth century.

The economic unit and main structure and institution in ancient China to sustain such a despotic system of mandate and rule was the family. How families, lineages, groups, and communities responded to state rule and centralized power in the Ming and Qing period is key to understanding the path towards modernization, against the backdrop of domestic and external conflicts, at the dawn of the nineteenth century. The wet-rice production of China during the early modern period seemed enough to maintain stable financial income in family groups leaving, therefore, farmers motiveless to seek efficient and innovative modes of production (Marks 1998; Bray 1986).

A relevant feature of the "despotic" system was derived from the cultural environment that rendered the merchant as a derogatory and negative figure in ancient Chinese society. Due to the "Asiatic Mode of Production" in which the government was the sole agent upholding the power, economy, and socio-cultural structures, the institutions and agents that emerged from this system acted as coordinator between cities and supplier of basic economic resources such as wealth, energy resources, raw materials, and food and shelter. And more importantly the government and its structures were the only capable and legitimate organizer of daily 
life and massive infrastructure projects such as building dams and irrigation systems or deflecting the river track to prevent flooding. This was a direct link to the livelihoods of the people, and ultimately the government (and its officials) was placed at the top of the ancient Chinese social hierarchy.

The irreplaceable and unquestionable management function of the government thus engendered high social status to governors, officials, and local bureaucrats. The rise of any emerging power through accumulation of capital, outside the realm of official authorities and central government, was therefore deemed a potential threat. The invisible force of money might jeopardize the power and despotic rule of the emperor creating a parallel or invisible state through non-official institutions within the state. This potential danger appeared to be occurring in southern China, as new rich families, lineages, and communities emerged through trade activities in south China markets, Southeast Asia, and the Pacific markets connected with the Americas and Europe. The accumulation of American silver in private family fortunes that escaped the official coordination of the central government was the major threat, and in the long term the main cause that set China into an economic depression at the beginning of the nineteenth century.

The central government's aim of maintaining intact the superiority of bureaucrats and officials abolished any prospects of social mobility for middle and lower social groups. The rising economic power of merchant groups posed a threat to bureaucrats by endangering their social status and hegemonic position (Rowe 2001). Thus, the government intensified the idea that the merchant class had low social status, ethics, and morals being ruthlessly driven by the worldly and evilly forces of money. The Qing (Manchu, non-Han rulers) despotic emperors, mainly Qianlong, stressed this idea on trade through autarky and mercantilist policies in which the state must be the main power intervening in the economy and trade affairs. Qianlong also indirectly emphasized the concept of race and ethnicity due to the foreign origins of the dynasty. In 1755 in a memorial to the emperor issued by local officials it was described that forty boatmen "without pigtails" were seen on a trade vessel along the coast of Macao. ${ }^{2}$ Even though it was verified that part of the crew were foreigners who had settled in Macao, Qianlong's concern to control southern China

${ }^{2}$ FHAC, Lu Fu Zou Zhe (hereafter LFZZ), reference (hereafter ref.) 03-0092-060. 
trade groups and maritime activities was growing. Manchu communities had the tradition of keeping their hairstyle with a pigtail—they commonly had the habit of shaving the head and leaving partially a round part of the hair tied back. Han rulers, as the Han ethnic group was the dominant one in China, forbade the cutting of hair as part of traditional Han culture.

In a gesture of symbolic alliance with the Han population, after the arrival of the Manchu (foreign dynasty) and its aim of showing the authority and power of the new dynasty, Shunzhi emperor decreed the "hair shaving order" in 1644: "keep your hair or keep your head" [ liú tóu bù liú fà, liú fà bù liú tón 留头不留发,留发不留头]. ${ }^{3}$ In the following years and centuries, insurrections and revolts would sporadically take place. Consequently, Qing emperors had special concerns on racial and ethnic cultural habits and traditions such as "hair identity" as a symbol of loyalty to the empire. Cultural habits in dress style and fashions such as hairstyles were ways to control the population (Zhu 1998).

This created over the centuries a gloomy social environment which prevented, at least in official circles or socially acceptable, merchant groups promoting themselves and becoming assimilated with the upper middle classes. The government aimed to intervene and control merchant groups' endeavours. The aim of keeping and likely creating a new cultural identity by Qing rulers, who expanded westwards the borders of the Middle Kingdom and therefore controlled new lands and ethnic groups, was a central policy. This was based on maintaining the despotic rule and control of the government with officials and bureaucrats being the main hegemonic social agents. Within this idea the officialdom aimed to perpetuate the mentality that being a merchant was decadent and lacking in ethics and values, while being a government official provided honour and social status for the family and community in ancient Chinese society (Adshead 2000).

As a result, this provoked a social bottleneck between the emerging business families and officials and bureaucrats. This internal confrontation in China created in the long-term social endogenous causes that impeded economic growth and caused the perpetual stagnation of the economy from the eighteenth century onwards. Therefore, there was not an emerging bourgeoisie, or only within non-official circles and institutions, from the sixteenth century when new capital (American silver) was

${ }^{3}$ FHAC, Han Tan, Jiang Yin Cheng Shou Ji (1673-1704). See also the work by Zhao Ximing (1968). 
entering into south China via the Iberian empires. The lack of a bourgeoisie identity which led to the formation of an "open society" for investments and scientific innovation was a crucial factor that aborted any possibility of an industrial revolution bringing modernization and economic transformation to China in the eighteenth and nineteenth centuries.

The central government's policies in keeping bureaucrats and officials at the core of society set most individuals of the vast population of China to a certain inaction (Chen 2011; Wang 2007). This socio-cultural feature might be linked with the Chinese term wéi 为 and wúwéi 无为. Wéi 为 might be interpreted as the application of the force of will-power. It is based on the social conviction that objects, animals, men, and women should do what it is expected from them and what they are commanded to do. Wúwéi 无为 might be defined as the contrary force which respects the course of nature and leaves things and facts to flow alone. The forces of nature are leading events and actions by which individuals might benefit by accepting the outcomes instead of going against their natural flow by not interfering (Fernandez-Armesto 2001). As Bertrand Russell once said: "creation without possession, action without self-assertion, development without domination" (Russell 1922, 1956: 566-578, 584).

In the case of Taoism, ancient China had basic beliefs regarding the surrounding world and its natural phenomena. However, these primitive explanations and legends didn't later evolve into a systemized religion, which was also supported by deep philosophic background and content. Instead Taoism emerged, which is a social phenomenon somewhere between religion and philosophy ( $\mathrm{Lu}$ 1999). Such primitive beliefs, together with the deeply rooted inaction feature of individuals according to their social belonging and ranking, were also an important factor that prevented China from achieving higher levels of modernization and stable economic growth in the early modern period (Chen 2013; Yan 2012; Ma 2010). 


\subsection{Self-Sufficiency ANd Market-Orientation: The "Supremacy Dilemma” and "Power Paradox" of the Middle Kingdom}

As noted earlier, scholarship with a marked Eurocentric perspective has predominately focused on core economic areas and hegemonic regions perpetuating the great divide between the West and East and coreperiphery economies (Wallerstein 1979; O’Brien 1982). Whereas studies marked by a stiff Eurocentric perspective (Landes 1998) criticized revisionist studies about the global economic role of East Asian economies (mainly China), scholars leading revisionist studies initiated by Gunder Frank and other Californian scholars (Wong 1997; Pomeranz 2000; Von Glahn 1996) reoriented Western theories and socio-economic and cultural achievements of European regions at the dawn of the Enlightenment and the Industrial Revolution. Duchesne launched a counter-attack to Californian scholars defending Eurocentric arguments against the role of East Asian regions (mainly China) in world economic development.

Despite the deficits between Asian and European markets, Eurocentric theses are based on rigid assessments dependent on debatable statistics such as Europe's share of world trade in 1720 was $69 \%$ whereas Asia's was 11\% (Rostow 1978; Aldcroft and Ville 1994). And Asia's share of the European trade was only $4 \%$ in 1830 . However, these amounts do not include Asian (basically China) Western imports from Europe and the Americas through the Pacific market, and these imports were based on the re-exportation activities of decentralized and unregulated markets, the smuggling trade, which makes it difficult to draw the traceability of imports-exports.

End-markets show a better picture of the capital flow and circulation of global goods (Flynn 2019; Perez-Garcia 2019). Non-official institutions and other economic agents (Perez-Garcia 2013) were transforming the forces of production and supply through the introduction of changes in the demand. Intra-regional European markets were also at the centre as they were connecting European territories with East Asia. This was more obvious during the eighteenth century when maritime trade and the navigation system became more developed, overlapping regions and integrating markets as Frank envisioned (Frank 1998) and Duchesne showed his scepticism (Duchesne 2001). The key aspect is to show empirical evidence of the trade nodes and networks that were operating in both Pacific and Mediterranean regions in which alliances among 
merchants and the trust and information to undertake long-distance business and ultimately circulation of defined global goods, contributed to such overlapping markets escaping the realm of official institutions (Greif 2006).

The "brokerage system" based on merchant alliances, partnerships, through the well-known practice of commenda (Pryor 1977) was a premodern mercantile practice of business intermediation to implement maritime insurance contracts, partnership agreements, bills of exchange, and double-entry bookkeeping (Braudel 1949). In international entrepôts such as Marseille in western Mediterranean Europe and Macao in south China, we might observe such overlapping markets in what can be defined as the "Asian-Mediterranean brokerage system" (Perez-Garcia 2019; Gipouloux 2011).

These markets and world regions defined by the multipolar, or polycentric, dimension was introduced by Frank's work, and needs to be further developed by presenting new empirical evidence from Western and Eastern sources such as the trade records of the Archive de la Chambre de Commerce de Marseille and the Historical Archive of Macao, among others, that show detailed information of European demand for Chinese goods (silk, tea, porcelain), and the inbounds of American silver into south China markets. The revenue, in silver, through taxes levied by the Qing state, which were registered in the Local Gazetteers of China, was of lower quantity than the inflows of silver through the smuggling trade. Thus, the question posed by Duchesne: "what percentage of European trade was intra-European? What percentage of world trade was Asian, and what percentage was European?" (Duchesne 2001: 435) seems to be biased as it just seeks to put the emphasis on world core economic regions using official statistics and indices (exports-imports) dismissing local economic interactions through non-official trade and institutions. This informal agency and trade shaped a polycentric world economic system, featured by local connectivities, which demonstrates that the upcoming modern nation-states cannot be defined as the sole dominant players.

Further observation of another variable depicting trade networks, the intermediation and density of economic nodes and social agents, might challenge traditional explanations about why the industrial revolution occurred first in northwestern European regions (i.e. Great Britain and the Netherlands). Unregulated markets, the role of despotic and absolute monarchs and landlords of Southern Europe, or the unquestionable 
Mandate of Heaven (Qian 1966) by the emperor in Beijing and the self-sufficiency of the economy of the Middle Kingdom prominently stand out as relevant cultural features that pushed back modernization, technological innovation, and economic growth.

Conventional economic interpretations keep unidirectionally observing Kondratieff " $\mathrm{B}$ " contraction and " $\mathrm{A}$ " expansion phases as the main phenomena to analyse economic growth and world trade expansion, locating the date of the great divergence and market integration based on price indices in 1820 - arguably questionable data and numeracy (Williamson 1985; Chilosi and Frederico 2015; O'Rourke and Williamson 1999; Duchesne 2001; Frank 1998).

According to this rationale following Wallerstein's thesis that in some historical periods there were circumstances for certain economies to further develop in which a rise in wages and access to cheap supplies (i.e. coal, raw materials, foodstuffs) from the colonies placed European regions into favourable conditions in comparison to their Asian counterparts. Consequently, European areas had the incentives to invest in new technologies. This means that the European Scientific Revolution was based on an economic process rather than a cultural one, which contradicts my argument that hierarchized societies and interventionist states and institutions, mainly those of Catholic Europe or the Qing dynasty, were the main factors for stagnation and economic backwardness.

Overseas trade from the Americas, the Pacific, the Indian Ocean, and the slave trade with Africa generated the capital accumulation and lowcost resources that prompted the Industrial Revolution in northwestern Europe. Despite the counter-arguments stating that oceanic commerce was a marginal factor for economic growth in core areas (O'Brien 1991; Floud and McCloskey 1994; Bairoch 1993; Engerman 1972; O'Brien and Engerman 1991, 1996), the rising consumption of overseas goods and trade profits came from non-official trade and unregulated markets. This generated prosperity in certain areas such as Britain, Belgium, or the Netherlands (de Vries and Woude 1997) in which both official and nonofficial institutions were intertwined due to the favourable geography for smooth channels of distribution through retailers, peddlers, wholesalers, and environmental conditions.

The repertoire of research that outlined the British exceptionalism (Berg 2005; Overton 1996; Inikori 1989; Williams 1966) during the Industrial Revolution period by giving a predominant role to the supply side, the vast national output of British markets and the inner strengths 
of Britain to seek incentives for technological innovations, dismisses the outside forces of the vastly decentralized and unregulated markets from peripheral Europe, i.e. Cadiz-Seville, Lisbon, Marseille, among other relevant entrepôts and trade nodes, that concentrated a high accumulation of overseas goods (mainly from south China markets) and American silver.

This American silver was again relocated in south China which acted as main magnet for the flow of capital due to the rising demand for Chinese goods and re-exportation in European markets. The analysis of such polycentric world trade zones, the connectivities of intra-regional and maritime markets through the agency of merchants and non-official institutions, demystifies the thesis that the major driver that led to economic growth and modernization in Europe was the nature of the British internal economy and its ability to respond to the stimulus of external trade, such as the role of law, constitutional government, and the awareness of liberty and democracy (Vries 2015; Vries 2010; O'Brien 1991; Bairoch 1993).

Instead of providing analysis on endogenous and exogenous causalities on European advanced regions' nature and performance to further develop during the eighteenth century in comparison with East Asian regions through the connection with overseas markets using historical sources from China and Europe, the Eurocentric (Anglocentric) scholarship has constantly focused on the uniqueness and exceptionalism of Western civilization having as pivotal axis the British empire and its colonies with statistical evidence and numeracy from Western sources (Humphries and Schneider 2019; Vries 2015; Darwin 2012, 2013; Berg 2011; Belich 2009; Darwin 2009; Overton 1996; Inikori 1989; Williams 1966).

Once claimed by John Brewer as the "error of our ways" (Brewer 2004), British exceptionalism's failure to undertake proper comparisons among world regions and to think globally is still very much present in recent research which perpetuates as valid the traditional view of Europe (and by extension the British world) as the hegemonic power and culture that brought modernization to the West. This view prolongs the idea that Europe has been the most creative and unique civilization since ancient Greeks developed theoretical science and thinking, citizenship, democratic politics, and in essence, the birth of modern society (McKendrick 1982). Such exceptionalism is coloured with a profound ethnocentric perspective and cultural superiority. 
To observe and better understand Needham's question and logic to compare the paths of economic growth and modernization between China and European regions (mainly comparisons have been carried out between China and Great Britain dismissing other European regions), other schools, basically British scholarship, have indirectly followed the same pattern of analysis uniquely leading us to a "Eurocentric (Britishcentric) trap." This is that Britain was more efficient in managing cheap labour, rising wages, and triggering incentives for innovation and, therefore, had a more productive agrarian system. In China the rationale was the same for cheap labour and supplies (i.e. use of energy sources), but the choice and motivation to invest in innovation, in new technologies, and to increase wages was not the same.

Any transformation was viewed as a loss of the essence of Asian (Chinese) cultural values because such changes were believed to be brought into China from the outsiders (Westerners) seeking control of the Middle Kingdom. This set China onto what we might call a "supremacy dilemma" or "power paradox" within East Asian cultural values. In other words, China was the hegemonic power and most advanced economy in the twelfth and thirteenth centuries when medieval European kingdoms were stagnant. It also led the cultural essences of East Asia over territories and regions (Korean peninsula, Japan, western regions) which some of them were progressively occupied in the Ming and Qing dynasties setting China as the hegemonic power of the region (Ko et al. 2018). Absolutist regimes, in which this Chinese model fits, and as Debin Ma also confirmed in his research, sets the "paradox of strong power and weak governance" (Ma 2014).

Strengthening its power by expanding its borders during the Ming and Qing dynasties fully pushed China into the "supremacy dilemma." This was based on keeping the new territories, and its communities and minorities, unified and controlled by the strong power and coercive forces of the mandarinate and the complex institutions and bureaucracy that held rigid control of society (Zhou 2012). An alternative could have been transforming and adapting the newly acquired regions and growing population through new incentives in productivity, technology, efficient use of natural and agrarian resources, open overseas trade system, rising wages, and reduction of institutions, potentially developing and modernizing the economy in the way that Great Britain and the Netherlands later did during the eighteenth century (Greif 2005). 
This implied the use of new technologies, likely most of them discovered in China, but they were more developed in the West. The arrival of Jesuits in the Ming and Qing Court were the main social agents to introduce such technologies and discoveries, but in the end the Jesuits' "Western" technology and its application were dismissed as a potential threat against keeping the Middle Kingdom unified in both cultural and political terms. That is what might define the "power paradox": China seemed to develop further than its European counterparts (Dincecco 2014) having economic features of modern capitalism, but in the long term its economy was stagnant due to the institutional constraints that aimed to control new communities and minorities in southern and western provinces under the mandarinate rule that overshadowed the society and culture.

The rigid interventionism that defined the autocratic state of the Qing regime fostered informal socio-economic networks, external resource dependency, a lack of information from the central government in Beijing to long-distance provinces, a non-compliance culture, an inefficient tax system, and therefore a weak state capacity (Ma and Rubin 2019). This plus the highly hierarchized society and governance based on Confucian values (Weber 1951) which prevented social mobility, scientific transformation, and innovation, made the Middle Kingdom "closed" to the outside world for the "inner fear" of losing the supremacy of East Asian (Koyama et al. 2018), and Chinese, cultural values.

Analysing these socio-cultural factors complements the incomplete and biased statistics and numeracy from both Chinese and European historical sources, demonstrating that the debate on the inner causes of economic development between Asia (China) and western regions is in essence based on imperfections and multiple variables of a diverse and growing geography of China's borders in the Ming and Qing dynasties (i.e. population growth, trade indicators, goods and capital flows, implementation of technology, business alliances, energy resources, cultural features of local communities, etc.). The polycentric approach, connectivities between peoples and regions, and the holistic view of the socio-economic process of transformation (Frank 1998) by which the historian can observe it from local changes is paramount to avoid the conventional bias. These are the Eurocentric (Anglocentric) and/or Sinocentric approaches which seem currently to be connected to a neo-Cold War narrative that seeks to set world hegemonic territories. These new narratives might be legitimated by historical research (the -isms) and ultimately perpetuate 
the great divide between the West and the East, or superior and inferior world regions.

For instance, the "supremacy dilemma" or "power paradox" that began in the Ming and Qing dynasties continued throughout the twentieth century up until the present day. China has tried to adjust itself to the rules set not merely by Western powers, but through the changes of world scenarios (Acemoglu 2005), and therefore makes a strategic rationale in its "governing dynamics" (Nash 1950) to be a decisive player in the economic and political world order (Fudenberg and Tirole 1991; von Neumann and Morgenstern 1944). The nature of the Chinese market has been merely characterized by mercantilism and autarky protecting, unifying, and securing its borders, and by exporting more than importing ready-to-use goods (Besley and Persson 2010).

From the sixteenth to the eighteenth century, the linchpin and node of south China markets with American markets was through the connection with the Spanish empire in Manila which served as main entrepôt for the constant flow of Chinese goods to American colonies and the outbounds of American silver to China. Thus, Spanish-controlled colonies in the Americas became progressively orientated to: (1) export raw materials, energy sources, cheap labour; and (2) drain off high volumes of silver to Asian (mainly China's) markets, almost 2/3 of the total share (Flynn and Giraldez 2010), instead of going to Spanish markets. Consequently, in the long run, the Americas predominately became exporters and dependent on more developed economies for the introduction of finished manufactures (Frank 1969).

Analysing commodity chains to study the world economy system is an accurate tool to observe within such decentralized and unregulated markets of the Pacific (connecting China with the Americas) the flows and exchanges of Chinese goods for American silver (Hopkins and Wallerstein 1986). Following Wallerstein's thesis, the complexity of the economic system of the Pacific region, which geographically encompassed $1 / 3$ of the world market (Flynn 2019), absorbed the small mini-systems, worldempires (Iberian, Ming and Qing China), as well as competing with world economies. This ultimately fostered a high accumulation of capital (American silver) into the hands of private merchants and local gentry in the southern provinces of China which both the Ming and Qing states were unable to control (Chang 1955).

Establishing long-distance trade for the introduction of goods into Chinese but also European and American markets, and linking processes 
of the formation of worldwide trade networks and business partnerships, allowed a significant accumulation of capital (American silver) that neither the Spanish nor the Qing empire (Tilly 1990; Huang 1974; Irigoin and Grafe 2013) could control in the eighteenth century even with the implementation of stiff mercantilist and interventionist decrees on overseas trade. The traceability of large amounts of goods (Chinese items in Western markets, and European and American ones in Chinese markets) through cross-referencing historical sources from China and Europe (i.e. probate-inventories, trade records, and confiscation records) allows us to show the worldwide circulation of these goods beyond the realm of state and official institutions.

The structure of these commodity chains goes further than the classic bilinear scheme of raw materials and finished goods. Instead of this rigid format, the complex construction of connections between economic nodes of production, supply, and formation of social network analysis to delimit the trade zones in which business companies (smugglers, longdistance partners, and brokers) operated for the introduction of goods seems a more accurate method. This allows us to analyse and scientifically construct from the local perspective the role of mini-economic systems, capital absorption, and inequality and dependence in the long run of economic zones and their ultimate participation into a more global economic system.

The geographies (loci) in which economic agents acted (traders, companies, non-official institutions, etc.) generating operations in the form of simple economic transactions (individual exchanges in local markets) or more complex financial systems (i.e. commenda, bills of transactions, credits, loans, or all-risks insurances for maritime trade, etc.) provide us with an accurate evaluation of the diverse operations in decentralized and unregulated markets of the Pacific, and also of Mediterranean regions (Greif and Tabellini 2017). In these spaces, commodities circulated globally creating secular trends and cyclical rhythms in local economies that can be partially observed through the official figures and statistics of import-export data.

The expansion and contraction of such trade cycles were only a product of minimal transformations, interventions, and partial reforms (decrees, bans, prohibition laws) of the states which in the long term could not eradicate or prevent the operations undertaken by non-official or nonstate controlled economic agents. Institutions either implemented by the state or in local markets (families, lineages, shrines, guilds, among others, 
either in Western or Chinese regions) had a similar logic and function. Regardless of the appearance and structure of these institutions, as feudalist or capitalist, they were all commercial establishments responding to the demand of outer markets with the aim of controlling and securing profits.

The rise, transformation, and metamorphosis of such institutions based on land power, control and access to local and afar markets, and family alliances in the southern provinces of China (Jiangsu, Fujian, Zhejiang, Guangdong), Manila in the Philippines, New Spain, South America (Lima-Callao) (Suarez 2018), Buenos Aires (Ibarra 2019), and Europe (Cadiz-Seville, Marseille) from the sixteenth to the eighteenth century showed the demand for goods and creation of new markets that confirmed the existence and "sprout of capitalism" and features of world economy in the early modern times.

This "sprout of capitalism" was commercial rather than industrial or technological and innovative-orientated in nature, another argument that confirms why China did not modernize earlier than Europe and why the economy of the Middle Kingdom stood behind some of its European counterparts. The less developed regions, i.e. Asian or American (Hausberger 2018), were not isolated from more advanced regions or trade zones (Flynn 2019), but they acted as providers of goods, capital, and information to operate in distant markets creating a polycentric (PerezGarcia 2019) and decentralized economic system between polities and empires.

However, such market dependency, with less capability to be more technologically advanced and productive, set the region into a selfgenerated industrialization. In other words due to the self-sufficiency of the Middle Kingdom as provider of all kinds of raw materials and basic supplies but with less capacity to transform manufactures within more sophisticated systems of production placed its economy into a dependency of tributary states of the border of south China and Southeast Asia, and the capital incentives prompted by silver accumulation. In the long term the economy of Qing China pursued self-development by non-participation in the process of global transformation, revolution and breakthroughs in technology, and ideas and political systems compared to some regions in Europe where these changes were progressively introduced (economically in northwestern Europe, and politically in France). 


\subsection{The Local Gazetteers and State Capacity in Qing China}

To provide a new evaluation of the great divergence debate within a micro-analysis of the economic performance of specific regions of China, mainly coastal areas and southern provinces, the data of Local Gazetteers of China [zhōngguó difāng zhi 中国地方志] seems a relevant approach when looking at the state capacity of the Middle Kingdom to manage the economic and human resources (Chu 1942; Wang 1987; Will 1985). I am aware that the data of the Local Gazetteers on population and taxes numeracy are biased and, in many cases, inaccurate, especially data from the Qing dynasty. However, even from such bias and inaccuracy we might infer the incapacity of the Qing state to manage the economic and human resources acquired from the new lands and provinces incorporated within the Qing expansion (Howland 1996; Perdue 2010). Such expansion needed a new mobilization of resources and efficient administration which was not the case for the Qing dynasty. Appointments of new officials, supervisors, and bureaucrats were undertaken, but their skills and techniques were poor when counting households, age of family members working, and the numbers subject to pay tribute [gòngfù 贡赋]. As another disincentive to taking a thorough census, the salaries of these officials were very low.

This could be one of the main reasons for the inaccurate data of the census of population [rénkǒn pǔchá 人口普查] of the Local Gazetteers of the Qing dynasty. This census was meant to levy taxes on a family based on the number of family members working. The aim in presenting the following section of figures and partial data on the population of parts of eastern and southern China is not to account for population or provide annual series of taxes levied by the Qing state. The goal is precisely to demonstrate within such numeracy the low capacity of the Qing state to manage the economic resources and have an efficient system and bureaucracy for tax collection. This might re-evaluate within a micro level the so-called "footsteps" of the great divergence in provinces, prefectures, and counties of Qing China.

Wealth was localized in some eastern and southern regions such as Guangdong, Fujian, Jiangsu, Zhejiang (Dow 1965), lower Yantze delta, and Jiangnan (Chan et al. 2015; Fang 1996), the latter very well studied by $\mathrm{Li}$ Bozhong $(1985,1996)$. But this wealth was in private hands through the initiative of local merchants and artisans who in many cases 
bypassed the state supervision. This shows a disparity, basically high inequality, of the wealth distribution in China regions that shows the contradictions of a wealthy state with enough economic and natural resources, but with an inefficient system to manage such resources and, therefore, provide the incentives to individual entrepreneurship.

Conventional scholarship has used Chinese sources such as the Local Gazetteers to measure population or to look at tax data. In different ways scholars such as Cao Shuji (2001), He Bingdi (Ping-ti Ho) (1959), Mark Elvin (1973, 2004), Roy Bin Wong (1997) or Lee and Campbell (1997, 2002), among the most relevant, have approached this source to measure population growth in China and the Malthusian pressures of Chinese population. Through gazetteers, I re-evaluate the state capacity of the Qing state by presenting a problem previously not solved which is to show the economic interactions of new Qing officials in eastern and southern localities and how this was correlated with an efficient management of local economic resources and population. ${ }^{4}$

The Local Gazetteers are local sources the government administration and local officials or gentry compiled from the tenth century to the late Qing dynasty about general rules, boundaries of the region, topography (see Map 3.1), ancient monuments, official buildings and city walls, water, examinations, population, land and taxes, market towns, local products, local customs, biographies, literature works by local people, and miscellaneous (Ho 1959; Chen 1965; Mostern 2008). In the Song dynasty local authorities collected data more efficiently which was compiled in the Local Gazetteers (Mostern 2011). During the Ming dynasty data (Franke 1983) were compiled to give information for the 1461 general gazetteer, thereafter they were re-edited, and for the Qing period new editions were made for nearly all areas (Leslie 1973) which made the results and information unreliable. John K. Fairbank mentioned that the Local Gazetteers is "more than 3,000 multivolumed works available in collections. They provide a ramified wide-ranging record - geographic and economic treatises, historical narratives with extensive documentation, collection of numerous bibliographies, and essays on customs and religious institutions - for all administrative areas of the Chinese empire,

\footnotetext{
${ }^{4}$ See the work by Xia Mingfang (2012) for the evaluation of Smithian features of China's economy during the Qing period.
} 


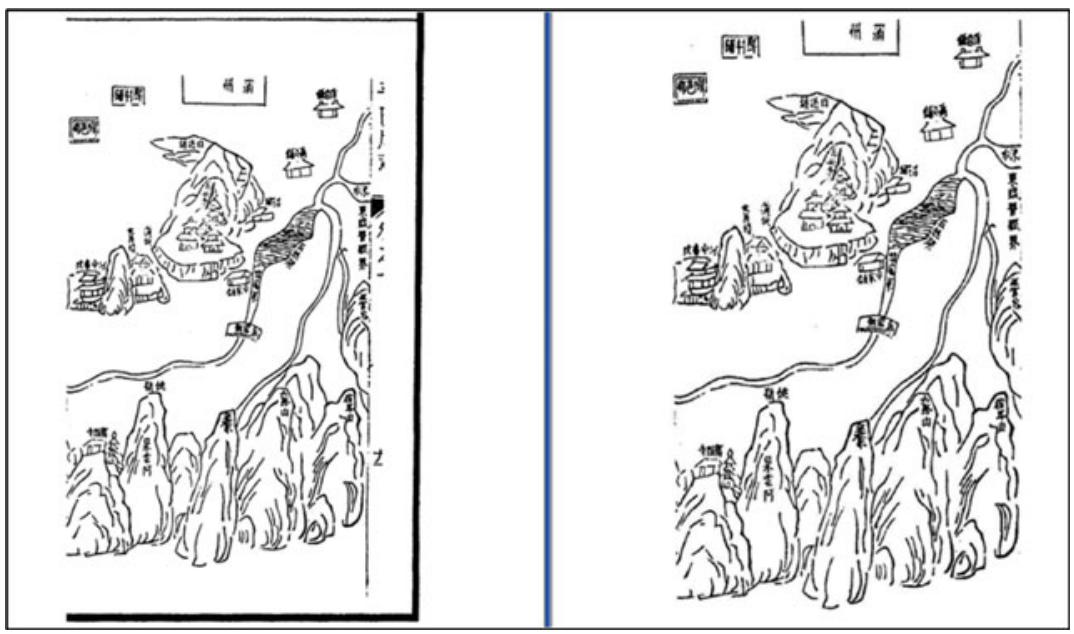

Map 3.1 Puzhou town in Shanxi province

Source: Renmin University of China Library (hereafter RUCL), Rare Book Collection, Zhongguo Difang Zhi, Shanxi province, Kangxi reign

from the county on up to the province... Their 'statistics' are not those of the modern-minded government statistician or economist" (Ho 1959: ix). I analyse the capacity of the Qing state through the examination of the economic performance at regional level, province [shèng 省], prefecture [fú 府], subprefecture [zhōu 州], county [xiàn 县] in south China (Hervouet 1957). Rather than using aggregates from GDP data (see Fig. 3.5), an analysis of the administrative system from the local basis might give us a better insight into understanding the functioning of the Qing government and the economic performance during this time.

There are doubts about Maddison's estimates to measure population growth (see Fig. 3.5) in China from the Song dynasty until the present as this data has been aggregated without counting the disparities of local records from the Song to Qing dynasty, mainly considering the discrepancies and inefficient system of the Qing period to account population as many data were omitted and under-registered. 


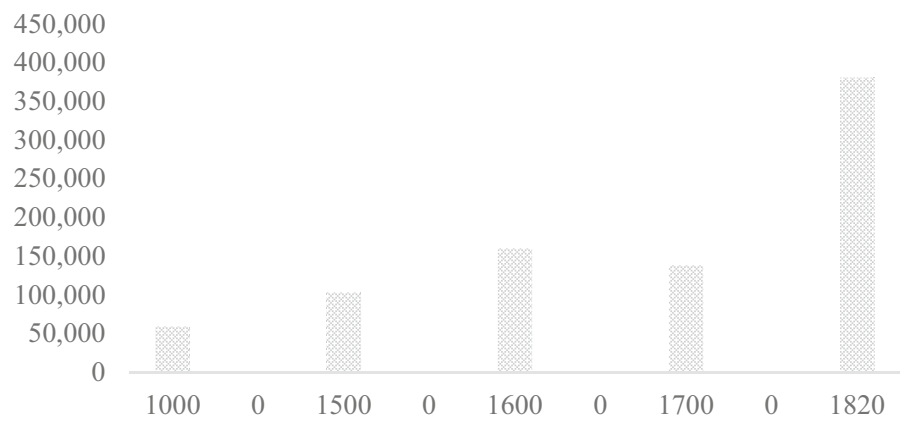

Fig. 3.5 Maddison's estimates on population growth in China, 1000-1820 Source: Maddison, A., Monitoring, 1995. Maddison, A., The World Economy, 2001. Maddison, A., The World Economy: Historical, 2003

There are serious problems and errors in some Chinese sources such as the Local Gazetteers due to an inefficient record system of Qing bureaucrats and officials, such as household and tax registration (Ma and Yuan 2016), which makes it a daunting task for historians to accurately develop a series of annual tax and population data (Shi 2008; He 1998). The shallowness of source analysis, archival collection, and data analysis in PRC scholarship is therefore common (Long 2011; Shi 2011; Zhao 2011). There was under-registration in population data even though appointments of local officials and bureaucrats rose in number in the Qing period. But their salaries were low and therefore their techniques to perform their work got worse (Shi and Yi 2008; Iwai 2004; Hamashita 2006; Wang 1973). The channels of information between the emperor and officials in southern provinces malfunctioned the governance (Sng 2010), and the imperial policy taxation evolved towards a prefixed annual tax quota and informal local taxation (Ma 2014). The fiscal system of the Qing dynasty was a continuity of the preceding Ming dynasty, but the techniques and methods of registering population and tax collection in the Qing period never improved. Public statistical records were subject to deliberate falsification, governmental laxity, and technical limitations for accountability. Table 3.2 and Figs. 3.6 and 3.7 correspond to early Ming China when the system was more workable and efficient than that of Qing China. The households and number of family members of southern counties 
3 THE MANDATE OF HEAVEN, THE RULE OF THE EMPEROR ...

Table 3.2 Population of southern China regions, 1371-1376

\begin{tabular}{|c|c|c|c|c|c|c|}
\hline & \multicolumn{2}{|l|}{1371} & \multicolumn{2}{|l|}{1376} & \multicolumn{2}{|l|}{1376} \\
\hline & Households & Mouths & Households & Mouths & $\begin{array}{l}\text { Growth } \\
\text { rate } \\
(\%) \\
\text { Mouths }\end{array}$ & $\begin{array}{c}\text { Growth } \\
\text { rate (\%) } \\
\text { Households }\end{array}$ \\
\hline Jixi county & 9787 & 41,414 & 9942 & 42,483 & 2.51 & 1.55 \\
\hline Changshu county & 62,285 & 247,104 & 61,211 & 263,414 & -1.75 & 6.19 \\
\hline $\begin{array}{l}\text { Huizhou } \\
\text { prefecture }\end{array}$ & 117,110 & 536,952 & 120,762 & 549,485 & 3.02 & 2.28 \\
\hline $\begin{array}{l}\text { Suzhou } \\
\text { prefecture }\end{array}$ & 473,862 & $1,947,871$ & 506,543 & $2,160,463$ & 6.45 & 9.84 \\
\hline
\end{tabular}

Source: Chi-his HC (1581 ed.), 3.1b-2b. In Ping-ti, Ho, Studies on the Population of China, pp. 6, 7,17

mouths 1376

mouths 1371

households 1376

households 1371

$\begin{array}{llllll}0 & 500000 & 1000000 & 1500000 & 2000000 & 2500000\end{array}$

- Suzhou prefecture $\quad$ Huizhou prefecture

Fig. 3.6 Population in Suzhou and Huizhou prefectures [ fur 府], 1371-1376

mouths 1376

mouths 1371

households 1376

households 1371

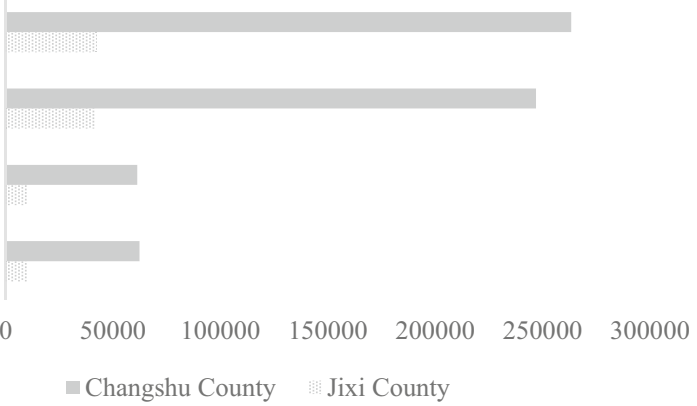

Fig. 3.7 Population in Changshu and Jixi counties, 1371-1376 
and prefectures for this period present less disparities in data registration of spans of short periods. Here below are presented data of Jixi and Changshu counties, as well as Huizhou and Suzhou prefectures featured as dynamic local economies. Sudden and irrational changes and contrasts in population and fiscal registration will appear in the Qing dynasty.

The average household in the above tables was four persons per household. The method applied by the Ming government was to manage 110 households into a $l i$ 邻. The so-called ten $l i$ [headmen] were chosen from the biggest number of adult males within their household and who paid a higher amount of taxes. The remaining 100 households were divided into ten již 甲[one jiǎ had ten persons as head of households]. Normally a walled city, called fāng 坊, had 110 units of households (Ho 1959: 7 ). The total population of China by the end of the fourteenth century likely reached the figure of $65,000,000$. The early Ming population was smaller due to decades of chaos and wars and the eventual defeat of the Mongol dynasty. Population was decreasing in the first half of the fifteenth century, and the second half of the fifteenth century showed a stationary fluctuation of circa 60,000,000 (Ho 1959: 9) (Fig. 3.8).

There are two milestones in China's historical population and fiscal administration system. The first one was the unprecedent and effective fiscal and labour reform by Hongwu emperor 洪武帝 (1368-1398) based on the account of the total population. Records on labour services [called Huangze or Yellow Registers] were compiled between 1381 and 1382, and thereafter revised in 1391 (Ho 1959: 3). This accounting system incorporated land-survey maps and land-tax handbooks. The second milestone during the same period was the completion and enumerations in nature and quality of such land maps and tax handbooks, the so-called Fish-Scale Maps and Books. It was not until Qianlong's reign, in the last quarter of the eighteenth century, when China had a comparable system in quality like the one of the early Ming dynasty. In 1370 the Board of Revenue was the main institution in imposing on provincial and local authorities to get the population officially registered under their jurisdiction. The Qing fiscal regime was based on hierarchy and centralized power which in nature was a continuity of the Ming system based on Confucian values and the mandate of the emperor as demonstrated in the previous section.

At the beginning of the sixteenth century, and thereafter until the end of the Ming dynasty and during the Qing dynasty, the li-jiza method to register population by officials became unfeasible. The main reasons were 
3 THE MANDATE OF HEAVEN, THE RULE OF THE EMPEROR ... 107
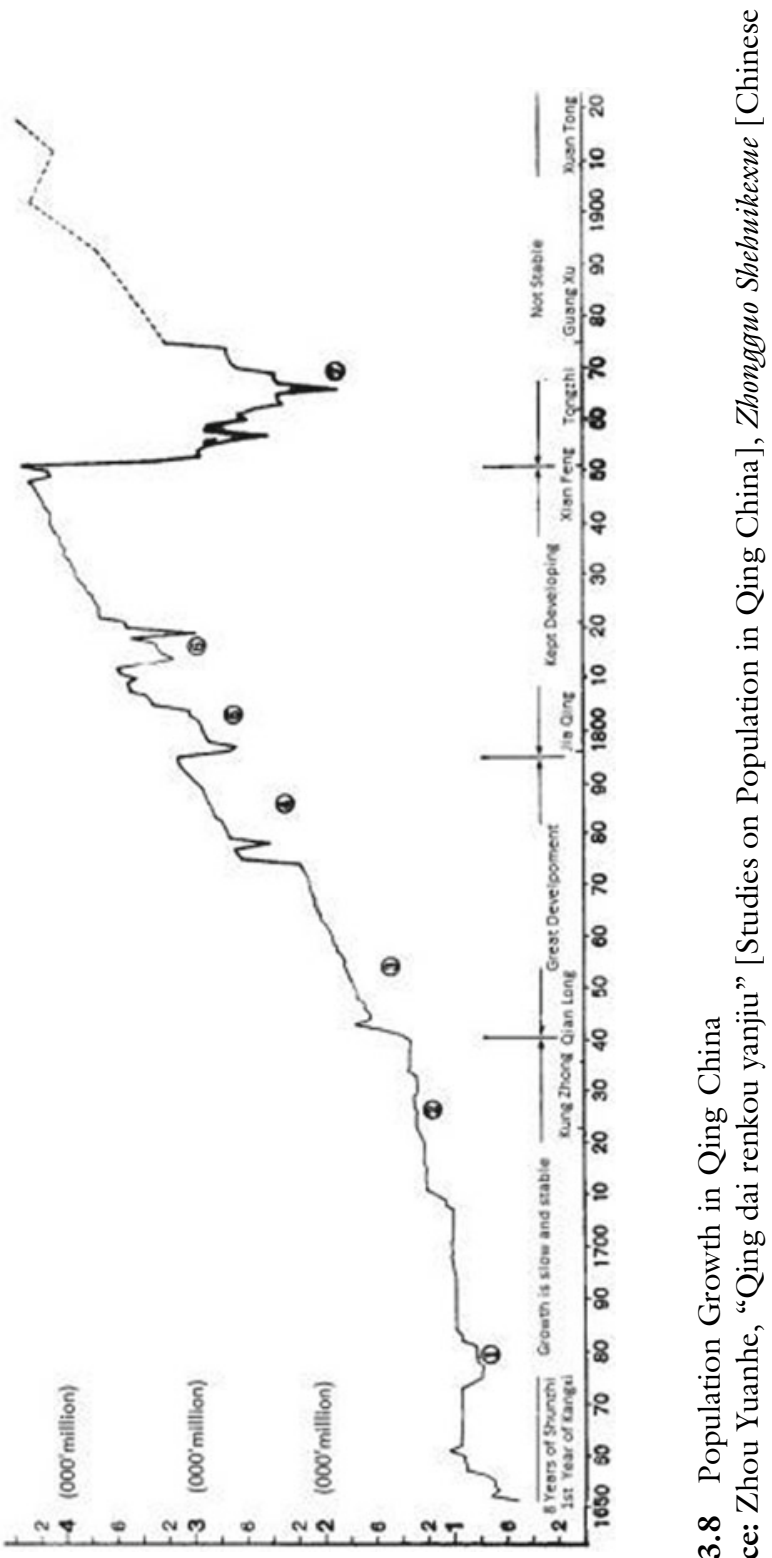
the following: (1) the corrosive influence of a rising money economy, the steady influx of American silver (Von Glahn 2019; Cao and Flynn 2019; Ho 1959: 11) after 1514 with the arrival of the Portuguese (de Sousa 2010, 2019; Perez-Garcia 2019; Boxer 1959; Boyajian 2008; Oka 2010); (2) alliances between the gentry and local government to evade labour services and land tax (McDermott 2013); (3) protection of rural interests by powerful landlords (Ho 1959: 10, 13; Skinner 1964, 1965a, b). Ownership of land was concentrated in the Lower Yangtze area, Guangdong and Fujian provinces' omission and evasion of population registration was fostered by landlords to protect the gentry; and (4) official peculation was also a factor for under-registration of population (low government payment for officials to perform their duty).

Officialdom was money-orientated due to the influx of high volumes of American silver into early sixteenth-century China. Chinese traders shifted the demand of silver from Chinese and Japanese to American silver which fostered and increased corruption. High appropriation of public revenue (see Fig. 3.9) such as taxes and labour-service payments by provincial and local officials became progressively common in the province of Fujian where trade with Europeans was very active. There was, therefore, a direct

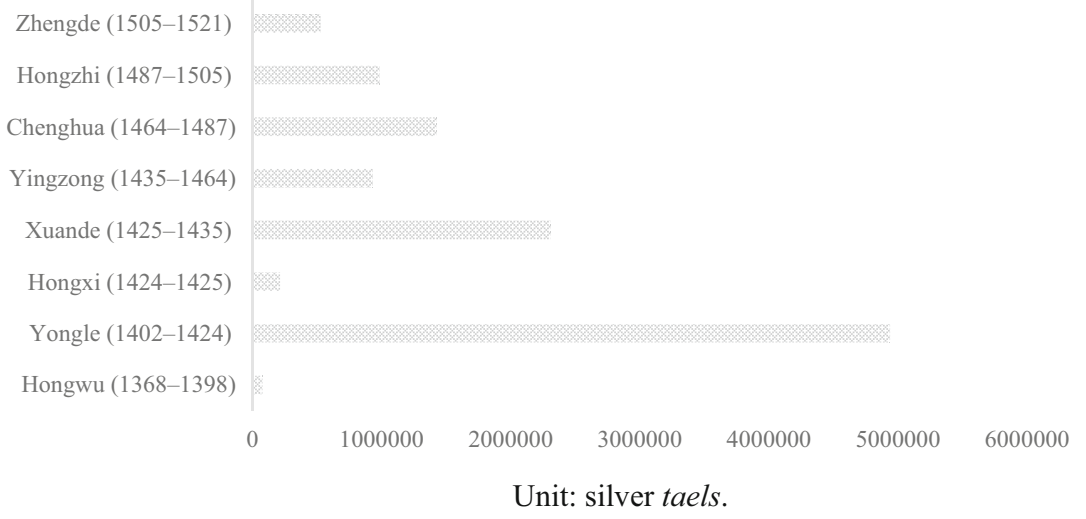

Fig. 3.9 Silver Income Revenue, 1368-1521

Source: Data adapted from Wan Ming, "Mingdai baiyin huobi hua: Zhongguo yu shijie lianjie de xin shijiao" [Silver Monetization in the Ming Dynasty: A New Perspective on China's Connection with the World], Hebei Xuekan [Hebei Journal], 5 (2004), pp. 145-154 
correlation between the introduction of American silver and the rising corruptive practices in southern China provinces (Ch'u 1962), mainly in the areas of Canton and Fujian. The under-registration of population due to the unworkable system carried out by local officials during the sixteenth century, and in the Qing period, incentivized these local officials to engage in contraband and illegal commerce which provided major profits in comparison to their official salaries (Brook 1999, 2010).

Contemporaries such as the Ming scholar He Qiao-yuan 何乔远 affirmed such practices and how official revenues were diverted to private pockets and government assistants and subjects. This scholar mentioned that "officially registered male adults, the so-called guān ding 官丁, paid only three tenths [guān qián 官钱] of a tael to local government. Male adults who are not into the registers are called si-ding 私丁 ['private', unregistered ting]. The private ding pays into the pocket of government underlings who charges roughly according to the size and economic status of the family. This is inevitable." 5 This system fostered alliances between powerful households and local government authorities in Canton counties to escape the fiscal burden. This provoked clan (lineages) alliances to evade official registration and therefore elude paying taxes.

The above-mentioned practices became progressively common, and, consequently, the system to register population and extract tax revenues in the late Ming period was imprecise. In late Ming, one ding was the equivalent of one male adult aged between 16 and 60 years old subject to labour services or labour service payment (Ho 1959: 22). Thus, the account of families and family members was arbitrarily compiled in the Ming dynasty, and such inaccuracy continued into the Qing dynasty. It is relevant to mention that Qing dynasty tax and labour calculations followed the procedure of compiling the Yellow registers after 1651 on a wider scale than the Ming registers. The Qing Yellow registers were mainly meant to account population and tax returns, whereas the Ming ones were based on accounting population and properties (Ho 1959: 24).

Such deep changes introduced in the Qing dynasty from 1651 meant that the registers collected on population were flawed and implausible. Map 3.2 and Tables 3.3, 3.4, 3.5, and 3.6 are arranged through the Local Gazetteers population and ding data related to prefectures of Guangdong

5 Shanghai Jiao Tong University Library (hereafter SJTUL), Dingxiu Database [鼎秀古 籍全文检索平台 ding xiù gǔjí quánwén jiánsuó pingtái], Rare Book Collection, Minshu, Chongzhen si nian (1639). Reference also in Ping-ti Ho (1959: 14). 


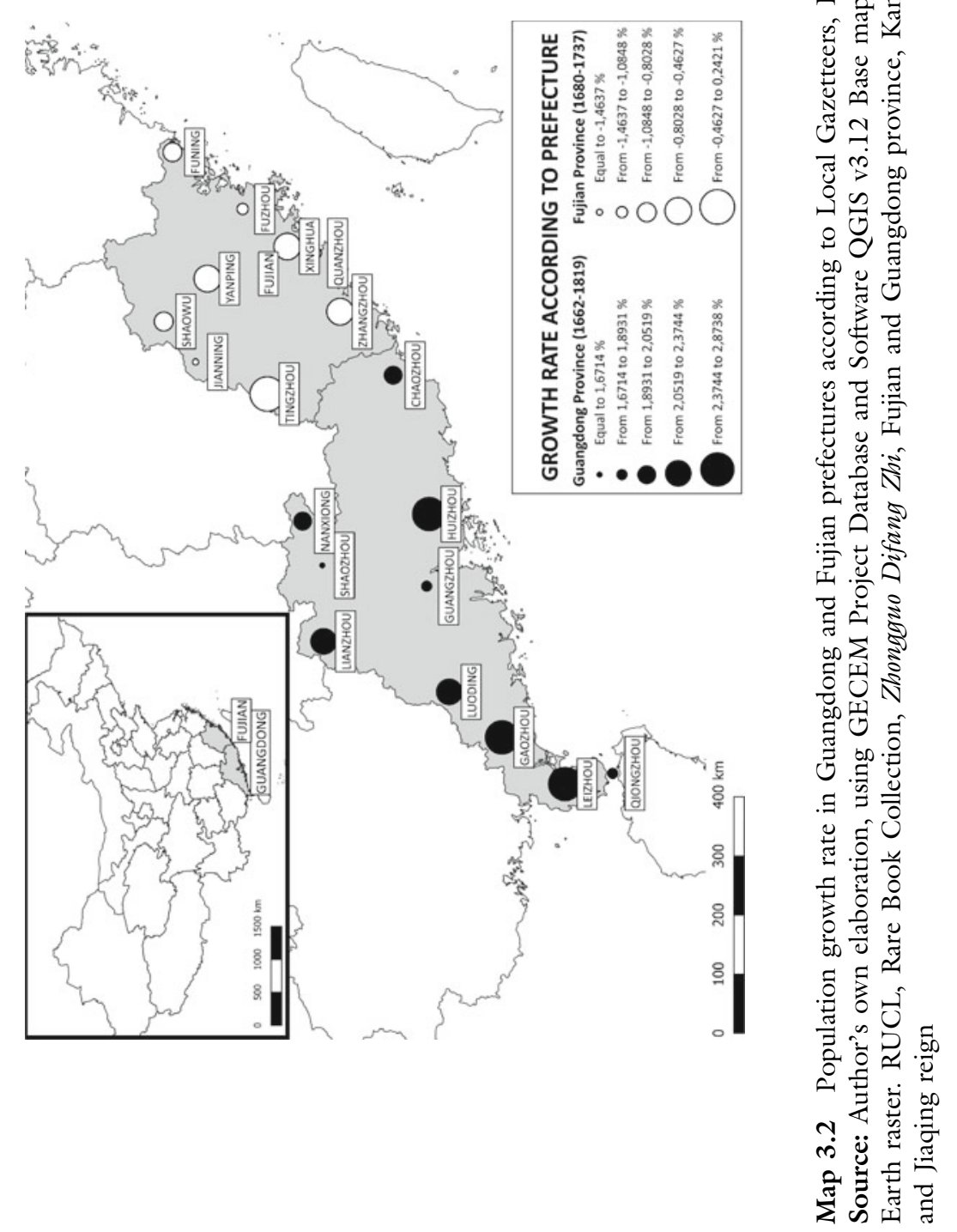


Table 3.3 Population data and growth rate in Guangdong prefectures [ $f u$ 府], $1662-1819$

\begin{tabular}{lrrrc}
\hline Prefecture & \multicolumn{1}{c}{1662} & \multicolumn{1}{c}{1663} & \multicolumn{1}{c}{1819} & Growth rate from 1663 to 1819 (\%) \\
\hline Guangzhou & 200,302 & 230,855 & $3,403,966$ & 1.86 \\
Shaozhou & 51,720 & 53,598 & 602,795 & 1.67 \\
Nanxiong & 9479 & 11,720 & 205,393 & 1.98 \\
Huizhou & 34,500 & 37,359 & $1,300,030$ & 2.87 \\
Chaozhou & 57,043 & 72,421 & $1,405,180$ & 2.05 \\
Gaozhou & 24,108 & 25,125 & $1,207,411$ & 2.68 \\
Lianzhou & 4,731 & 8777 & 269,960 & 2.37 \\
Leizhou & 4502 & 6902 & 368,840 & 2.76 \\
Qiongzhou & 46,733 & 47,153 & 728,889 & 1.89 \\
Luoding & 12,578 & 12,622 & 374,554 & 2.34 \\
\hline
\end{tabular}

Source: RUCL, Rare Book Collection, Zhongguo Difang Zhi, Guangdong province, Kangxi and Jiaqing reign

Table 3.4 Population data in Guangdong province, 1662-1819

\begin{tabular}{ccccc}
\hline Year & 1662 & 1673 & 1770 & 1819 \\
\hline Ding & 509,537 & 573,910 & 898,088 & $12,323,616$ \\
\hline
\end{tabular}

Source: RUCL, Rare Book Collection, Zhongguo Difang Zhi, Guangdong province, Kangxi and Jiaqing reign

Table 3.5 Population data and growth rate in Fujian prefectures $[f u$ 府], 1680-1737

\begin{tabular}{lrrc}
\hline Prefecture & 1680 & 1737 & Growth rate (\%) \\
\hline Fuzhou & 449,870 & 225,287 & -1.20 \\
Quanzhou & 240,435 & 129,117 & -1.08 \\
Jianning & 603,195 & 260,280 & -1.46 \\
Yanping & 315,115 & 217,589 & -0.64 \\
Tingzhou & 182,565 & 209,541 & 0.24 \\
Xinghua & 172,595 & 132,501 & -0.46 \\
Shaowu & 199,330 & 125,901 & -0.80 \\
Zhangzhou & 234,725 & 171,713 & -0.54 \\
Funing & 84,685 & 49,833 & -0.92 \\
\hline
\end{tabular}

Source: RUCL, Rare Book Collection, Zhongguo Difang Zhi, Fujian province, Kangxi and Qianlong reign 
Table 3.6 Population data in Fujian province, $1680-1830$

\begin{tabular}{cccc}
\hline Year & 1680 & 1737 & 1830 \\
\hline Ding & $2,482,515$ & $1,622,436$ & $17,347,799$ \\
\hline
\end{tabular}

Source: RUCL, Rare Book Collection, Zhongguo Difang Zhi, Fujian province, Kangxi, Qianlong and Daoguan reign

and Fujian provinces where household registers in the Qing dynasty were not properly carried out before and after Qianlong reforms. The reform introduced by the Qianlong emperor in 1741 changed this system, but data were still weak. The only available data for the Qing period are the annual ding returns. The use of such data to account for population is a very difficult, almost impossible, task for demographers. As mentioned earlier my goal in this section is not to show any alternative to account for population, but rather to show, as illustrative example, that it is precisely this inaccurate data of the Qing dynasty that indicates the low capacity of the state.

Today some scholars (Cao 2001; Zhou 1982) take the model of some early Qing scholarship (Parker 1899; Rockhill 1905; Willcox 1930) which is based on considering the ding, families, and population liable to taxes in the same terms. Their method to calculate the population is to multiply the ding digits for a given year by four, five, six, or anything statistically plausible for them. Early Qing historians who worked on China's population in the late nineteenth and twentieth centuries have been influenced by each other, accepting each other's estimates and figures. This can be observed through the wide acceptance of the estimates of China's population of circa $65,000,000$ inhabitants in 1651 , and circa 350,000,000 in 1850 (see Fig. 3.8).

As we can see in Table 3.3 and Map 3.2 the growth rate in the population of some prefectures of Guangdong province sharply rose from 1673 (Kangxi reign) to 1819 (Jiaqing reign). The population data system passed from under-registration in the Kangxi reign to over-registration in the Jiaqing reign, despite the Qianlong emperor's reforms. Even though there is a consensus that the population significantly rose in the MingQing transition, figures displayed in Table 3.3 showing the population growth rate in Guangdong prefectures are not plausible according to the data of the census of the Local Gazetteers from the Kangxi to Jiaqing period. 
Table 3.3 and Map 3.2 also show that the growth in some prefectures goes from $1.67 \%$ to $2.87 \%$ which is implausible as China's growth rate was $0.4 \%$ per annum from 1400 to 1850 (Ge et al. 2001; Ho 1959; Elvin 1973; Brandt et al. 2014; Lee and Wang 1999; Skinner 1987). The annual rate of growth of the whole population of China, according to Ping-ti Ho, and also confirmed in the data by Zhou Yuanhe, from $1779(275,000,000$ inhabitants $)$ to $1850(430,000,000$ inhabitants $)$, was between $0.63 \%$ and $1 \%$ (Zhou 1982; Ho 1959: 64). In the twentieth century the peak that China reached was $2.6 \%$ in 1968 , being $0.32 \%$ in the year 2020 (United Nations 2017; Roser et al. 2020).

Arbitrary estimates in accounting population were still carried out after Qianlong's reign. In 1819 during the Jiaqing period the total ding registered in Guangdong province according to Local Gazetteers was $12,323,616$ (see Table 3.4) which according to my argument is still an overrated figure. This figure has been taken as valid by current mainland China's scholarship to calculate the population of Guangdong for the year of 1819 as $21,392,000$ in the account book of department of revenue [hùbù 户部], with an estimate of $21,558,239$ as the final figure for Guangdong's population by the gazetteers of Jiaqing reign. Even though China's population was rising in this period, the figure provided by the gazetteers, and still taking as valid by some scholarship, is unrealistic and overestimated (Cao 2001: 191; Zhou 1982; Ye 1999; Jiang 1990). Something similar can be observed in Map 3.2 and Tables 3.5 and 3.6 that show population and ding data of Fujian prefectures.

The growth rate in all prefectures is negative, and only in Tingzhou prefecture in 1737, before Qianlong reforms on population registers, is the growth rate positive. Also, the data regarding the total number of ding in Fujian province (see Table 3.6) had sharp changes from the Kangxi to the Daoguan reign offering an unrealistic view of the population size. This shows that the Local Gazetteers' population registers were both under-registered and overrated during the so-called "High Qing" period [shèng qing 盛清], defined as economically prosperous, and also during and after the Qianlong reign and reforms. The system was unworkable being an indicator of the low capacity of the Qing state to create a stable socio-economic model to manage economic resources, mainly in southern provinces, as it is demonstrated through the data presented on the prefectures of Guangdong and Fujian. 
The reconstruction of China's population through Qing period data from 1651 until 1740 is no longer acceptable as the original Qing ding shares of several regions were fixed and later arbitrary evaluations were made. The “original" [shizài rénding 实在人丁] Qing quotas for ding tax followed the late Ming return system (see Illustration 3.1) (Ho 1959: 32).

Until the end of the Kangxi reign only half of the territories of the Middle Kingdom had completely merged the ding reform from tax labour service to tax land. And according to scholarship, it is only in the Qianglong years that the data on population and fiscal policies are a bit more, but not totally, reliable. This might lead us to the conclusion that the state capacity of the Qing government was low and inefficient in the implementation of tax reforms and administration of the economic resources of the empire, mainly the newly conquered lands. The ding returns from 1651 to 1740 of the alien dynasty, non-Han (Manchu), were never intended to indicate population, but to collect taxes. As we can observe in Fig. 3.10 below, the tax returns from the shizài rénding original population of Guangdong and Fujian provinces were quite lower than the ding figures. Even though data on population are not reliable, we might detect the

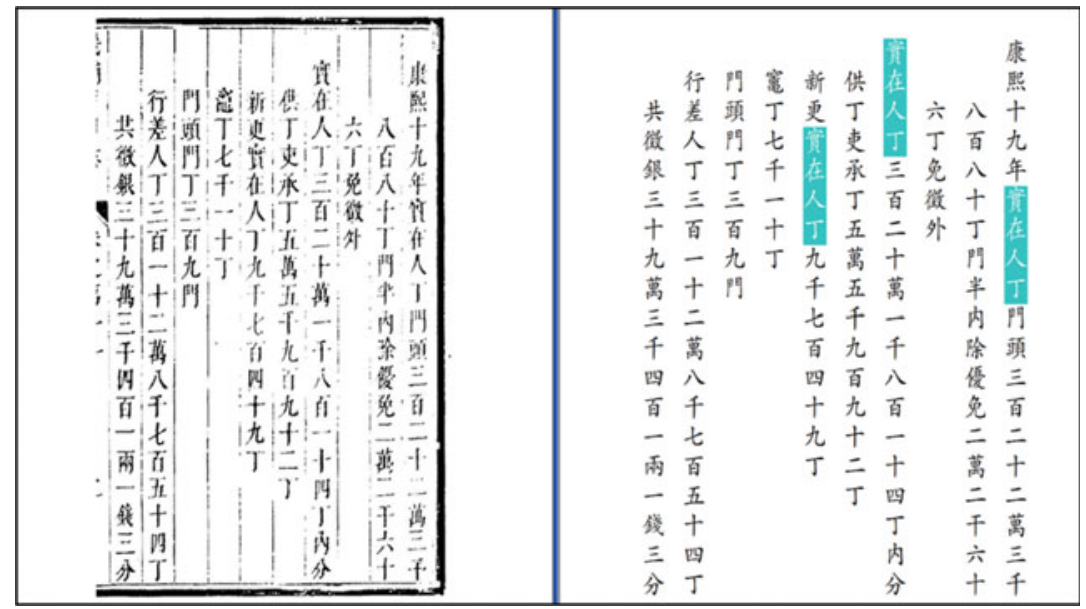

Illustration 3.1 Ding and Tax Returns in Hebei Province, 1680 Source: RUCL, Rare Book Collection, Zhonggno Difang Zhi, Hebei province, Kangxi reign 


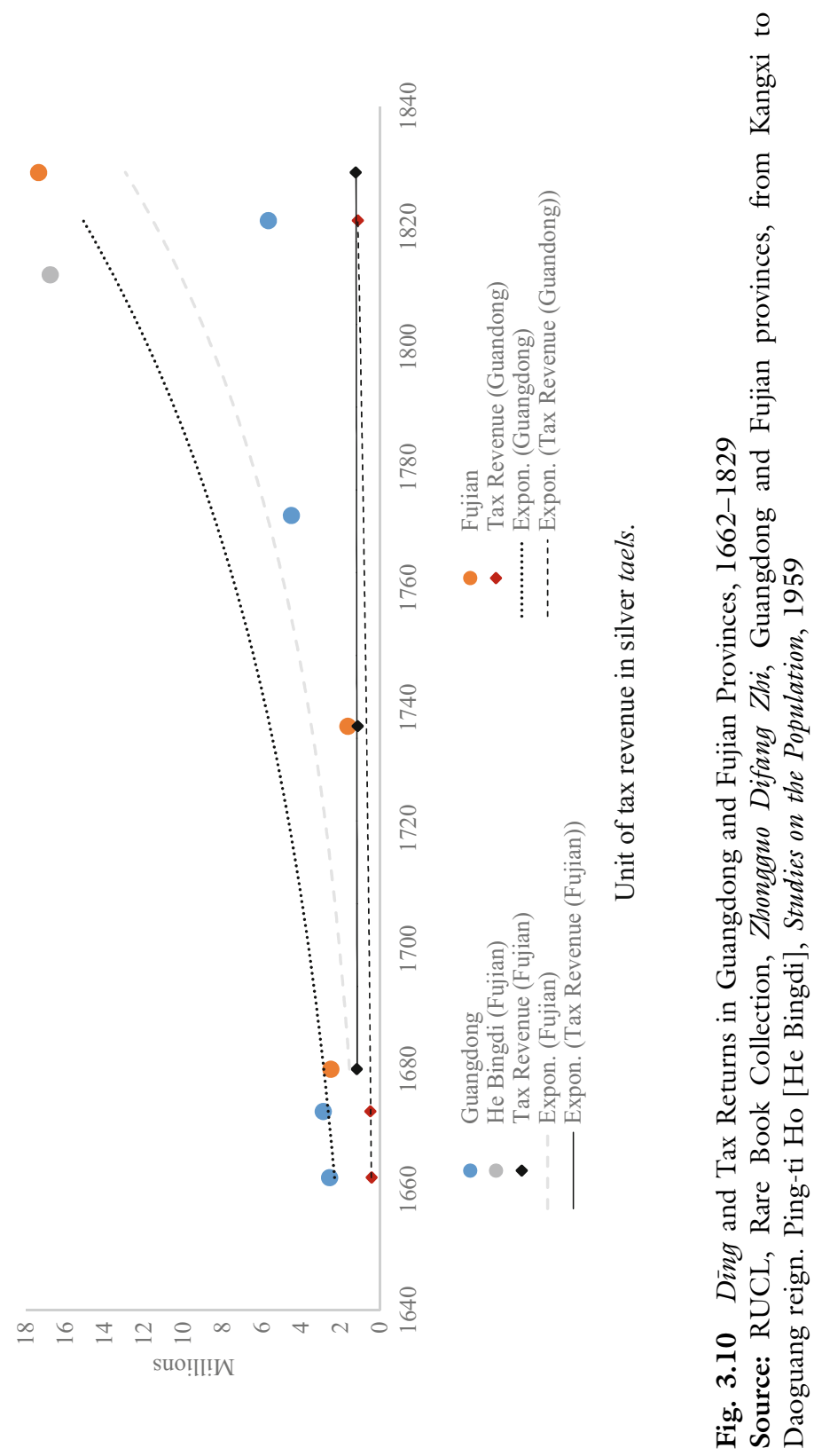


low capacity of the state to collect taxes as the tax digits were much lower than those related to population.

From 1741 to 1775 , the years of the Qianlong reforms to register population, data were still flawed and the system to register population did not have much in the way of improvements. We still observe (see Fig. 3.10) sharp fluctuations in population figures and a lack of uniformity in methods of population registers in the second half of the eighteenth century, whereas tax collection remained stagnant and with some slight decline. Through the data I present in this section, Ping-ti Ho's conclusions on the ineffective fiscal and population register system of the Qing dynasty (Ho 1959: 36, 37, 38, 198) are proven, mainly in the southern provinces where local alliances between officials and merchants were carried out as more profitable business. Merchants from Fuzhou, Canton, Suzhou, Shanxi, Nanjing, among other relevant areas, were engaged in the lucrative trade of introducing goods from western origins such as tobacco, wines, and liquors, American crops (i.e. sweet potato, potato, chili) (Perez-Garcia 2018; Cao 2004; Ho 1979), clocks, etc., and exporting silk, porcelain, and tea to western regions. This nonofficial system was rampant and uncontrollable by the central government of Beijing (Chang 1962) and is the subject of the next chapter.

In an effort to improve the system and eradicate such inefficient methods and under-registration of population which was having negative effects in collecting taxes and increasing the government public revenue, the Qianlong emperor decreed in 1740 an evaluation and review of the system of population registration. Ping-ti Ho mentions in his work a very illustrative passage of this decree and the response of the Board of Revenue which shows the low capacity of the state to register population, collect taxes, and most importantly to control the profitable business of long-distance provinces. Indirectly we can infer the worries of the government to control alliances between local officials and transient merchants who were not registered. Qianlong's decree mentioned the following:

In spite of the quinquennial [ding] assessments, provincial officials had hitherto been bound, in matters to the increase and decline [of the number of $d i n g]$, by administrative formality. They have scarcely realized that this matter is indeed the foundation of good government. From now on the provincial officials, should in the $11^{\text {th }}$ month of each year, send in detailed reports as to the changes in numbers of households and mouths...This will provide me with data for constant reference... (Ho 1959: 37) 
The Board of Revenue mentioned that after the completion of the ding assessments "there must not be any omissions and evasions." Evasions and diversion of public revenues were very common in the southern provinces, and so a group of high officials recommended that the data be compiled from the "original" [shizài rénding] population and tax quotas:

...the actual increase in population, can hardly be feasible in real practice... assessment has been based on-the-spot surveys and not on the ding registers. Moreover, people are scattered all over the countryside...If the local officials should be ordered personally to enumerate, they could not bear [such administrative burden]. Probably they would entrust such task to their office underlings. Besides some merchants are without fixed residence, as are the transients and those in services and on public errands...It is requested therefore that [the annual population enumeration] be stopped...There is no need to make a door-to-door enumeration. (Ho 1959: 38)

The population of provinces such as Sichuan, Hubei, Hunan, Fujian, or Guangdong was clearly under reported. Despite such attempts and reforms to improve the population and tax administration of China (Zelin 1985), the system was still confusing, and laws and decrees were very ambiguous. Local authorities purposely magnified population data after 1741 to satisfy the Qianlong emperor. The central government's mismanagement of securing an efficient system of information with local officials in procuring correct data on population could likely be explained as not wanting to put pressure on the local population, mainly Han communities, as high fiscal pressures were seen as an omen of faulty government and consequently might foreshadow the collapse of the dynasty (Ma 2014: 487).

The Manchu (non-Han) government, as a foreign dynasty ruling the Middle Kingdom, had in mind potential uprisings and local rebellions led by Han communities (Hung 2009). Therefore, in this particular issue, fiscal pressure was put more and more on foreign trade, and foreign communities. After his accession in 1736, Qianlong was concerned about the increasing accumulation of American silver by local communities in the southern provinces. In 1757 he established the Canton System [ȳ̌kóu tōngshāng 一口通商] (Liang 1999; Cheong 1997; Zhao 2013) enforcing Canton as the only port in China open for foreign commerce. 
This measure can be seen as a way for the Qing state to improve its low capacity of collecting taxes (Menegon 2017: 33; Wang 2017) from ding returns and mismanagement in registering population, as well as an attempt to control business alliances and activities through official institutions to eliminate contraband (Perdue 2017; Menegon 2017; Van Dyke 2011: 7-9). Within such measures Qianlong also seized an opportunity in controlling and levying taxes on maritime and foreign trade as a very profitable sector for the imperial treasury. Precisely in the year that Qianlong imposed the Canton System in 1757 and 1758 he collected more taels [liàng 两] of silver in the Canton Customs than the under-registered liang of silver levied in the whole Guangdong province in 1673, during the Kangxi emperor's reign (see Table 3.7).

Data from the Kangxi period are biased due to such under-registrations of the population system, but to make such comparison illustrates the low capacity of the Qing state to collect taxes and register population. And also, it shows the different contexts of the Kangxi period, when trade was more open, and the Qianlong period when trade was closed to all ports except Canton. These different economic and political contexts of the Manchu emperors, which has been widely recognized by the scholarship as the "High Qing" period [shèng qing 盛清] with its flourishing economy, as portrayed in this section show that a re-evaluation of this period should be made through further research as the capacity of the Qing state was weak and therefore the Chinese economy was stagnant. This implies that the so-called economic boom of the Qing state was a foot of clay. As Debin Ma mentions, such a weak state and

Table 3.7 Taxes levied in Kangxi ding registers and Qianlong Canton Customs

Year Tax in the dīng registers [silver liăng 两] Tax in Canton Customs registers

\begin{tabular}{|c|c|c|}
\hline 1673 & 491,310 & \\
\hline 1757 & & 325,320 \\
\hline 1758 & & 370,037 \\
\hline
\end{tabular}

Source: RUCL, Rare Book Collection, Zhongguo Difang Zhi, Guangdong province, from Kangxi reign. FHAC: Zhu Pi Zou Zhe (hereafter ZPZZ), 04-01-35-0331-002 
low administrative capacity had consequences for the long-run economic divergence between China and northwestern Europe. In particular, in light of the inefficient Qing institutions and bureaucracy, the fiscal system and state capacity should be re-evaluated (Ma and Rubin 2019: 279). China had the conditions to develop faster than its European counterparts but the high concentration of power, the institutional constraints with the multiplication of inefficient bureaucracy, the extra-legal taxation system, corruption practices, and an asymmetric system of information between provinces and the central government were endogenous factors that pushed back the economic development of China.

In 1772 (Ho 1959: 47) the quinquennial ding assessment was eradicated. In central, western, and southern provinces (see the data from Fujian and Guangdong provinces, Tables 3.3, 3.4, 3.5, and 3.6) accounting the population was still done arbitrarily. The long distance from Guangdong and Fujian provinces to the capital in Beijing, as well as the robust and increasing individualism of southern communities and families more orientated towards business and capital (silver) accumulation, which was more profitable, were determinant factors that contributed to corruption of the personnel and officials in provincial and local administration.

Qianlong realized that the [báojiar 保甲] system was not being thoroughly performed in the whole territory of the Middle Kingdom. Some measures were implemented to determine the real population of the empire, but as it is shown in the data presented in this section, such decrees and intervention of the government was not entirely successful as data were still falsified by officials. The goal was to register local population. However, the personnel and officials employed in this system were underpaid and these officials had to act not only as supervisors to register population but also as local police which worsened the performance of their duties (Ho 1959: 48).

The inefficiency of this system, which shows the low capacity of the Qing state, changed alongside with the socio-economic and political circumstances and strategies of the government. It is therefore proven in this section that across provinces, prefectures, and counties, as well as time spans, there existed a profound heterogeneity in the quality of the local accounts to register population due to the complex alliances between socio-economic and political forces (Brandt et al. 2014) and 
the difficulties of the central government in consolidating its power in long-distance localities. In the last quarter of the eighteenth century falsifications were still made. Qianlong's prestige and authority declined as he failed to manage and administrate government resources such as the work of provincial and local officials to record accurate population returns. This demonstrates that during the second half of his reign the economic condition of the nation started to deteriorate, being a long-term process of decline that had started earlier at the dawn of the eighteenth century.

The asymmetry in receiving information and communication from the highly centralized and political structure derived from the newly incorporated regions in the Qing expansion (Spence 1990) caused an endogenous problem in the fiscal capacity of the state, affecting its governance in the long term (Ma 2014: 485). The empirical evidence of the Local Gazetteers demonstrates the low capacity of the government to register population and levy taxes through an efficient system. ${ }^{6}$ This explains why the Qing government's tax revenue was not so high. This finding differs to some scholarship's (Wong 2012; Rosenthal and Wong 2011; Pomeranz 2000 ) belief that light taxation was due to the benevolence of the government following the Confucian rules of the good sovereign. In fact, the Qing emperors, mainly in the eighteenth century, were characterized by their interventionist rules and decrees whose aim was to consolidate their absolute regime and maximize their power and monopoly rents.

\footnotetext{
${ }^{6}$ Nominal Qing China's revenue (in silver units) was larger than those from the European or Ottoman states in the seventeenth and eighteenth centuries due to the size of China's population after the Qing expansion. But in real per capita terms, tax revenue was the lowest (Ma 2014: 488-489; Allen et al. 2011; Karaman and Pamuk 2011).
} 
Open Access This chapter is licensed under the terms of the Creative Commons Attribution 4.0 International License (http://creativecommons.org/licenses/ by $/ 4.0 /)$, which permits use, sharing, adaptation, distribution and reproduction in any medium or format, as long as you give appropriate credit to the original author(s) and the source, provide a link to the Creative Commons license and indicate if changes were made.

The images or other third party material in this chapter are included in the chapter's Creative Commons license, unless indicated otherwise in a credit line to the material. If material is not included in the chapter's Creative Commons license and your intended use is not permitted by statutory regulation or exceeds the permitted use, you will need to obtain permission directly from the copyright holder.

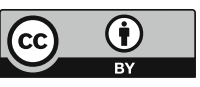

